\title{
Labor Market Institutions and the Distribution of Wages, 1973-1992: A Semiparametric Approach
}

\author{
John DiNardo; Nicole M. Fortin; Thomas Lemieux \\ Econometrica, Vol. 64, No. 5. (Sep., 1996), pp. 1001-1044.
}

Stable URL:

http://links.jstor.org/sici?sici=0012-9682\%28199609\%2964\%3A5\%3C1001\%3ALMIATD\%3E2.0.CO\%3B2-K

Econometrica is currently published by The Econometric Society.

Your use of the JSTOR archive indicates your acceptance of JSTOR's Terms and Conditions of Use, available at http://www.jstor.org/about/terms.html. JSTOR's Terms and Conditions of Use provides, in part, that unless you have obtained prior permission, you may not download an entire issue of a journal or multiple copies of articles, and you may use content in the JSTOR archive only for your personal, non-commercial use.

Please contact the publisher regarding any further use of this work. Publisher contact information may be obtained at http://www.jstor.org/journals/econosoc.html.

Each copy of any part of a JSTOR transmission must contain the same copyright notice that appears on the screen or printed page of such transmission.

JSTOR is an independent not-for-profit organization dedicated to and preserving a digital archive of scholarly journals. For more information regarding JSTOR, please contact support@jstor.org. 


\title{
LABOR MARKET INSTITUTIONS AND THE DISTRIBUTION OF WAGES, 1973-1992: A SEMIPARAMETRIC APPROACH
}

\author{
By John DiNardo, Nicole M. Fortin, and Thomas Lemieux ${ }^{1}$
}

\begin{abstract}
This paper presents a semiparametric procedure to analyze the effects of institutional and labor market factors on recent changes in the U.S. distribution of wages. The effects of these factors are estimated by applying kernel density methods to appropriately weighted samples. The procedure provides a visually clear representation of where in the density of wages these various factors exert the greatest impact. Using data from the Current Population Survey, we find, as in previous research, that de-unionization and supply and demand shocks were important factors in explaining the rise in wage inequality from 1979 to 1988 . We find also compelling visual and quantitative evidence that the decline in the real value of the minimum wage explains a substantial proportion of this increase in wage inequality, particularly for women. We conclude that labor market institutions are as important as supply and demand considerations in explaining changes in the U.S. distribution of wages from 1979 to 1988.
\end{abstract}

KEYwORDS: Wage inequality, kernel density estimation, minimum wage, unions.

\section{INTRODUCTION}

IT HAS BEEN WELL ESTABLISHED with a wide variety of measures and data bases that overall wage inequality increased substantially in the United States during the 1980's. ${ }^{2}$ Recent papers have argued that changes in the U.S. wage structure are primarily due to secular increases in the relative demand for skilled workers (Juhn, Murphy, and Pierce (1993)), and that therefore, factors such as international trade (Murphy and Welch (1991)) and skill-biased technological shocks (Bound and Johnson (1992)) have played a major role. Katz and Murphy (1992), among others, have argued that these changes in demand, in combination with the slowdown in the rate of growth in the supply of skilled workers, are the leading causes of the observed changes in the structure of wages. "Institutional" factors have also been implicated. Bound and Johnson (1992) have shown that the decline of "high-rent" industries explains some of the increase in the skill premium. Both Card (1996) and Freeman (1993) have found that de-unionization explains about one fifth of the increase in men's wage inequality over the 1980 's. On the other hand, much of the previous literature on the distributional

\footnotetext{
${ }^{1}$ We would like to thank Moshe Buchinsky, Daniel Hamermesh, Bentley MacLeod, Serena Ng, Robert Valletta, Jean Wohlever, a co-editor, and two anonymous referees for helpful comments and discussions. Fortin and Lemieux gratefully acknowledge financial support from the Social Sciences and Humanities Council of Canada and from the Fonds pour la Formation de Chercheurs et l'Aide à la Recherche, Québec.

${ }^{2}$ See Levy and Murnane (1992) for a recent survey of studies documenting the increase in wage inequality.

${ }^{3}$ See also Bound and Johnson (1992), Freeman and Needels (1993), Katz, Loveman, and Blanchflower (1995), and Katz and Revenga (1989).
} 
effects of the minimum wage has concluded that minimum wages are relatively unimportant. ${ }^{4}$

Most analyses have focused on education and experience wage differentials, as well as various inequality indices such as the variance of log wages or the Gini coefficient. We instead focus on the entire density of wages, a focus which has important consequences for our conclusions. To illustrate the importance of considering the density of wages, we display, in Figures 1a and 1b, hours-weighted kernel estimates of the density of hourly wages for men and for women over the period 1973-1992. ${ }^{5}$ A vertical line in each of the figures indicates the value of the federal minimum wage in the respective year. ${ }^{6}$ From these figures, there is clear evidence that the minimum wage compresses the lower tail of the density of wages, especially for women. ${ }^{7}$ This large "visual" impact of the minimum wage prompted us to investigate its role in recent changes in wage inequality more formally.

In this study we propose and implement a semiparametric procedure to analyze the role of institutional and labor market factors in recent changes in the distribution of wages. The main methodological contribution of the paper is to develop an estimation procedure that yields a visually clear representation of the impact of various explanatory factors. This methodological contribution is substantively important as well: despite all the carefully crafted research on this topic, little is known on exactly where in the distribution of wages these various factors exert the greatest impact.

For the sake of parsimony, we consider five explanatory factors: (i) changes in the real value of the minimum wage, (ii) changes in the unionization level, (iii) changes in the distribution of workers' attributes other than unionization, including industry affiliation, (iv) changes in the supply and demand of various categories of workers, and (v) residual or "unexplained" changes. Factors such as "skill-biased technological shocks" fall into the last category-residual changes. As in Bound and Johnson (1992), we focus our analysis on the period 1979-88 that witnessed the most dramatic changes in wage inequality and labor market institutions. We also contrast this analysis with some evidence from the

\footnotetext{
${ }^{4}$ The earlier literature on the distributional effects of the minimum wage (Gramlich (1976)) and the more recent work by Horrigan and Mincy (1993) both conclude that the effect of the minimum wage on the level of earnings inequality at a point in time is small. This is not incompatible, however, with changes in the minimum wage having a sizable effect on changes over time in wage inequality.

${ }^{5}$ These densities are estimated using data from the May dual job holding supplement of the Current Population Survey (CPS) from 1973 to 1978, and from the outgoing rotation group files of the CPS from 1979 to 1992 as explained in Section 2.

${ }^{6}$ The value of the federal minimum wage in real 1979 dollars is also reported in Table I. It rose and fell in erratic steps from 1973 to 1978, and fell in real terms every year from 1979 to 1989. Coverage expanded in 1976; the greater mass to the left of the minimum wage in the early 1970's is attributable to smaller coverage.

${ }^{7}$ The largest increase in the minimum wage took place between 1973 and 1974 . This explains why the compression effect is more evident in 1974 than in 1973.
} 

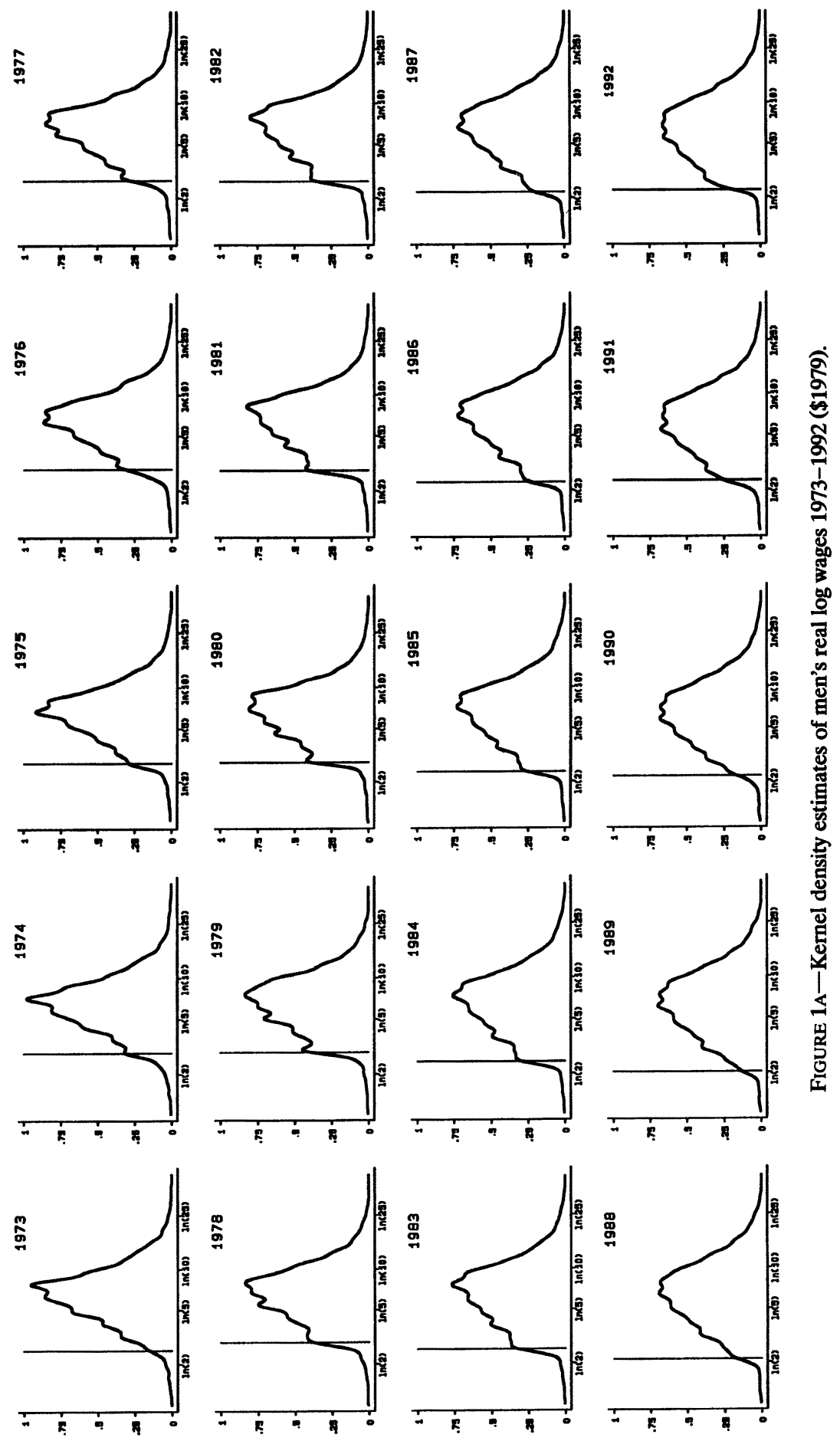

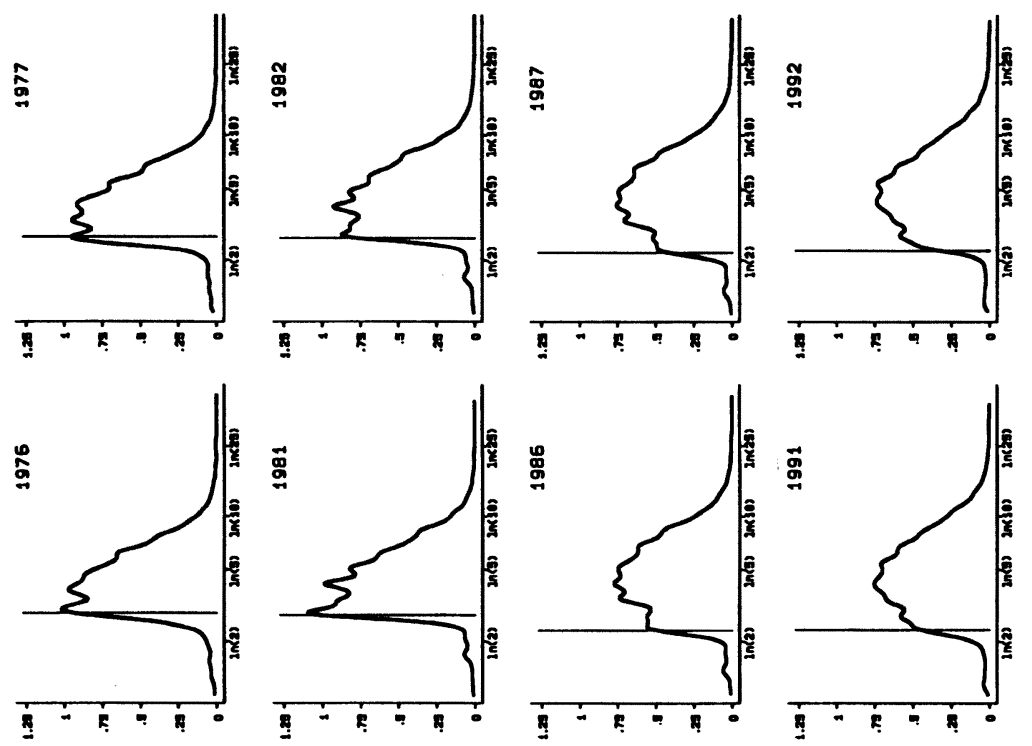

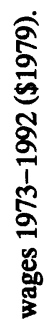
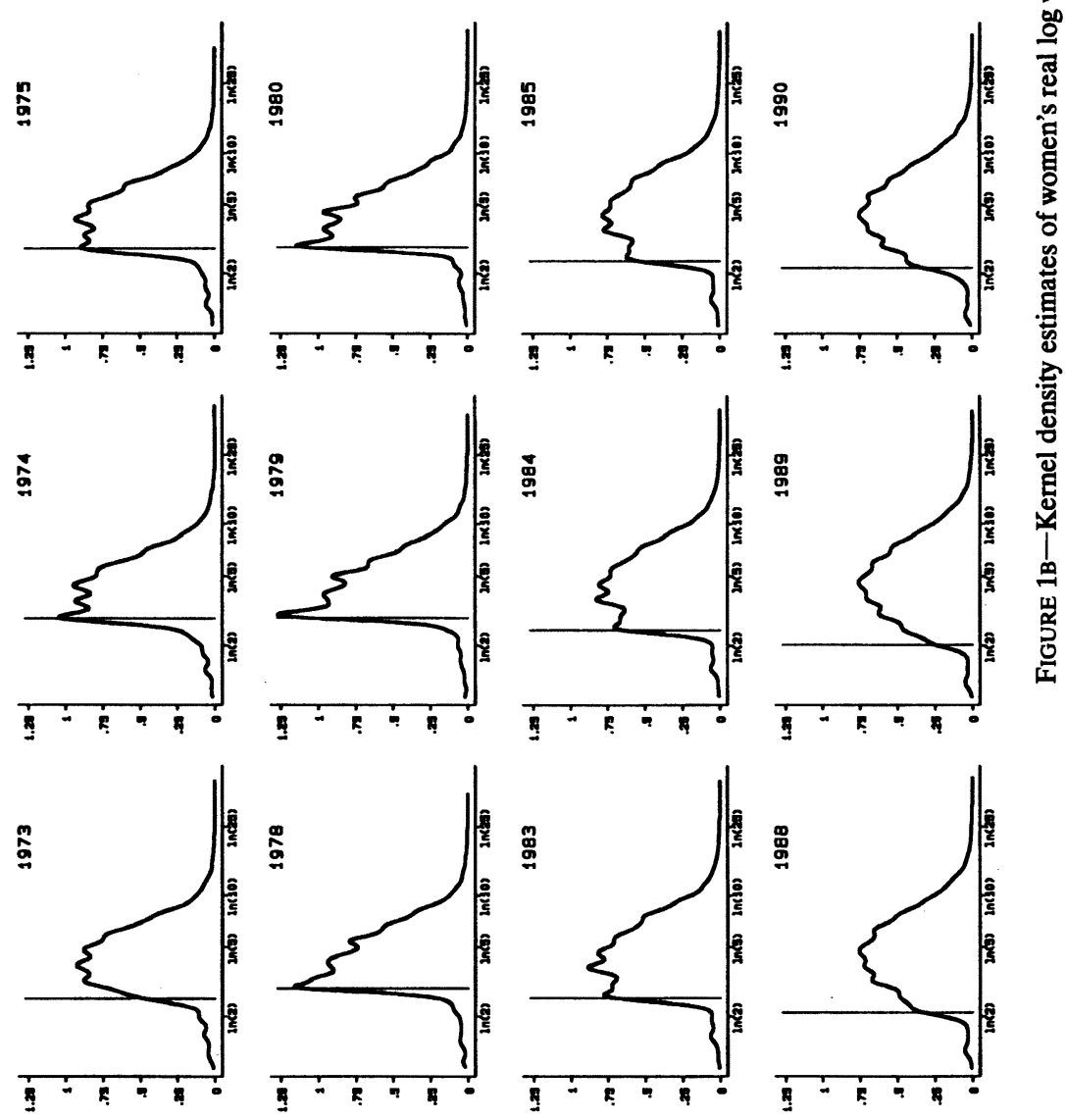
periods 1973-1979 and 1988-1992 during which wage inequality and labor market institutions were more stable.

Our semiparametric procedure is very much in the spirit of the familiar Oaxaca (1973) decomposition. These decompositions generally focus on means alone. ${ }^{8}$ In contrast, we work with the entire density of wages. Oaxaca decompositions are based on simple counterfactuals such as "how much would a worker, with the mean characteristics of the 1979 workforce, have been paid in 1988?" The key estimation problem in generalizing this type of decomposition to densities is to construct a counterfactual density that would have prevailed in 1988 if the characteristics of workers had remained as in 1979. We show in Section 3 that counterfactual densities can be estimated by applying known estimation methods, such as kernel density estimation, to appropriately weighted samples. ${ }^{9}$ Like the familiar Oaxaca decomposition, our decompositions ignore general equilibrium effects, and depend on the ordering of the explanatory factors. Despite these limitations, we argue that our procedure indicates the potential importance of the various explanatory factors.

In contrast with most previous work which has used earnings data from the March Current Population Survey (CPS), we use hourly wage data from the May CPS and from the outgoing rotation group supplements of the CPS. In Section 2.1, we describe our CPS samples and argue that they are key in identifying a potential effect of the minimum wage. The extension of classic kernel density estimation to the case of a weighted sample and the choice of bandwidth selector are explained in Section 2.2. In Section 3, we provide the details of our procedure for estimating the counterfactual densities associated with changes in individual attributes (Section 3.2), changes in the real value of the minimum wage (Section 3.3), and changes in the supply and demand for various categories of workers (Section 3.4). We then explain in Section 4 how we perform the density decomposition.

Our main results, focusing on changes in the density of wages over the period 1979-1988, are reported in Section 5. Like others, we find that changing unionization rates, changes in the composition of the workforce, and changes in supply and demand are important explanations of the change in wage inequality over this period. However, unlike previous research we find that the decline in the real value of the minimum wage over the period 1979-1988 had a large visual and quantitative impact on the distribution of wages. Indeed, we find that it explains up to twenty-five percent of the change in the standard deviation of men's log wages and up to thirty percent of the change in the standard deviation of women's log wages. It is also important in explaining changes in the standard deviation both between and within different groups of workers.

\footnotetext{
${ }^{8}$ Similar techniques have also been used to decompose summary measures of the distribution of wages into separate components. For example, Freeman (1980) decomposes the variance of log wages into the sum of the effect of unions and of the variance that would have prevailed in the absence of unions.

${ }^{9}$ This approach can also be used to estimate counterfactual inequality indices (Gini, Theil, differences between the 90 th and the 10th centile, etc.) or counterfactual wage differentials.
} 
The case of the minimum wage highlights the usefulness of showing precisely where the most dramatic changes in the distribution of wages occur. In fact, the visual effect of the minimum wage on women's wages is overwhelming and gives support to the quantitative estimates we also present. We finally show in Section 6 that labor market institutions remain important when we change the order of the main decomposition, and when we consider other time periods.

\section{DATA AND ISSUES IN DENSITY ESTIMATION}

\subsection{The Data}

This paper uses data from the CPS to analyze changes in the distribution of wages in the United States from 1973 to 1992. Starting in May 1973, the CPS surveys have regularly collected hourly or weekly earnings for each respondent's main job. From 1973 to 1978 , these wage questions were asked only in May, as part of the dual job holding supplement. Beginning in 1979, the wage questions were asked each month to people in the outgoing rotation groups (which represent one-quarter of all individuals in the survey.) Relatively large samples of workers are thus available to estimate changes in the distribution of hourly wages over the last two decades. The sample sizes are approximately 40,000 workers per year from 1973 to 1978 , and 150,000 workers per year from 1979 to 1992. The exact sample sizes, for men and women, are reported in Table I.

A major advantage of using these samples is that the wage measure collected is a good measure of a "point-of-time" price of labor. By contrast, most previous studies on changes in the structure of wages in the United States have used measures of average weekly earnings on all jobs which are available from the March CPS. ${ }^{10}$ One problem with this alternative earnings concept is that it depends on labor supply decisions, and on the choice of holding more than one job. The hourly wage measure used in this paper is thus more closely connected to theories of wage determination based on supply and demand that focus on the hourly price of labor. Similarly, the connection between the minimum wage and the hourly wage on the main job is more direct than the connection between the minimum wage and average weekly earnings on all jobs.

Another key advantage of the 1973-78 dual job supplements and of the 1983-92 outgoing rotation group supplements is that they contain information on the union status of workers. This variable is essential to any attempt to evaluate the effect of labor market institutions on the distribution of wages. Unfortunately, information on the union status of workers was not collected in the outgoing rotation group supplements from 1979 to 1982. It is nevertheless possible to obtain the union status in 1979 for a subset of workers by matching answers about unionization from the 1979 Pension Supplement of the May 1979

\footnotetext{
${ }^{10}$ For examples of studies using the March CPS, see Katz and Murphy (1992), Murphy and Welch (1992), and Juhn, Murphy, and Pierce (1993). These studies restrict most of their analysis to full-time (and sometimes to full-year) workers to minimize the confounding effect of labor supply decisions. These restricted samples are not necessarily representative, however, of the whole workforce.
} 
TABLE I

SAMPle MeAns From the Current Population Survey 1973-1992

\begin{tabular}{|c|c|c|c|c|c|c|c|c|c|c|c|c|c|}
\hline \multirow[b]{2}{*}{ Year } & \multirow[b]{2}{*}{$\begin{array}{c}\text { Minimum } \\
\text { Real Log } \\
\text { Wage }^{\mathrm{a}}\end{array}$} & \multicolumn{6}{|c|}{ Men } & \multicolumn{6}{|c|}{ Women } \\
\hline & & $\begin{array}{c}\text { Real Log } \\
\text { Wage }^{\mathbf{b}}\end{array}$ & Union $^{c}$ & Nonwhite & Education $^{d}$ & Experience $^{e}$ & $\begin{array}{c}\begin{array}{c}\text { Number } \\
\text { of } \\
\text { Observations }\end{array} \\
\text { of }\end{array}$ & $\begin{array}{c}\text { Real Log } \\
\text { Wage }^{\text {b }}\end{array}$ & Union $^{c}$ & Nonwhite & Education $^{d}$ & Experience $^{e}$ & $\begin{array}{c}\text { Number } \\
\text { of } \\
\text { Observations }\end{array}$ \\
\hline 1973 & 0.926 & 1.849 & 0.308 & 0.099 & 11.90 & 19.54 & 22155 & 1.437 & 0.142 & 0.123 & 11.99 & 19.27 & 15543 \\
\hline 1974 & 1.051 & 1.828 & 0.306 & 0.099 & 12.04 & 19.13 & 21030 & 1.417 & 0.140 & 0.126 & 12.08 & 18.77 & 15057 \\
\hline 1975 & 1.022 & 1.829 & 0.287 & 0.099 & 12.16 & 19.29 & 20881 & 1.433 & 0.139 & 0.128 & 12.21 & 18.61 & 15301 \\
\hline 1976 & 1.055 & 1.827 & 0.288 & 0.099 & 12.19 & 18.74 & 20878 & 1.445 & 0.138 & 0.126 & 12.28 & 18.01 & 15709 \\
\hline 1977 & 0.989 & 1.827 & 0.302 & 0.100 & 12.30 & 18.61 & 25411 & 1.437 & 0.160 & 0.125 & 12.34 & 17.94 & 19578 \\
\hline 1978 & 1.060 & 1.826 & 0.294 & 0.103 & 12.36 & 18.21 & 24011 & 1.436 & 0.158 & 0.128 & 12.35 & 17.63 & 18996 \\
\hline 1979 & 1.065 & 1.830 & 0.317 & 0.114 & 12.42 & 17.84 & 77000 & 1.451 & 0.170 & 0.136 & 12.46 & 17.38 & 63284 \\
\hline 1980 & 1.033 & 1.816 & - & 0.113 & 12.49 & 17.84 & 86977 & 1.450 & - & 0.136 & 12.56 & 17.42 & 73557 \\
\hline 1981 & 1.027 & 1.811 & 0.283 & 0.114 & 12.55 & 17.79 & 83444 & 1.454 & 0.149 & 0.136 & 12.59 & 17.48 & 71685 \\
\hline 1982 & 0.974 & 1.812 & - & 0.114 & 12.67 & 17.89 & 78885 & 1.469 & - & 0.134 & 12.71 & 17.53 & 69556 \\
\hline 1983 & 0.933 & 1.802 & 0.250 & 0.116 & 12.75 & 17.80 & 77395 & 1.470 & 0.149 & 0.136 & 12.79 & 17.42 & 68877 \\
\hline 1984 & 0.897 & 1.804 & 0.235 & 0.118 & 12.78 & 17.59 & 77754 & 1.474 & 0.141 & 0.140 & 12.84 & 17.37 & 69871 \\
\hline 1985 & 0.860 & 1.805 & 0.224 & 0.120 & 12.80 & 17.76 & 78728 & 1.481 & 0.135 & 0.141 & 12.88 & 17.41 & 71833 \\
\hline 1986 & 0.830 & 1.806 & 0.220 & 0.126 & 12.84 & 17.81 & 81603 & 1.490 & 0.132 & 0.144 & 12.92 & 17.58 & 75048 \\
\hline 1987 & 0.790 & 1.792 & 0.214 & 0.126 & 12.85 & 17.75 & 78694 & 1.490 & 0.129 & 0.144 & 12.95 & 17.55 & 73730 \\
\hline 1988 & 0.748 & 1.782 & 0.209 & 0.128 & 12.88 & 17.75 & 74661 & 1.492 & 0.129 & 0.145 & 13.00 & 17.64 & 70089 \\
\hline 1989 & 0.699 & 1.778 & 0.201 & 0.134 & 12.94 & 18.22 & 87123 & 1.496 & 0.128 & 0.152 & 13.05 & 18.15 & 80740 \\
\hline 1990 & 0.774 & 1.773 & 0.196 & 0.132 & 12.97 & 18.45 & 90480 & 1.502 & 0.127 & 0.152 & 13.10 & 18.35 & 84857 \\
\hline 1991 & 0.843 & 1.762 & 0.196 & 0.135 & 13.02 & 18.66 & 86809 & 1.509 & 0.128 & 0.152 & 13.16 & 18.61 & 82518 \\
\hline 1992 & 0.813 & 1.753 & 0.190 & 0.136 & 13.03 & 18.76 & 85627 & 1.519 & 0.129 & 0.154 & 13.17 & 18.81 & 81617 \\
\hline
\end{tabular}

a 1979 Constant Dollars.

b Standard deviations and other measures of dispersion are in Table A1.

${ }^{c}$ Union coverage is not available in 1980 or 1982

dStandard deviations of education range from 3.11 in 1973 to 2.68 in 1992 for men and from 2.61 in 1973 to 2.34 in 1992 for women.

e Standard deviations of experience range from 14.01 in 1973 to 11.83 in 1992 for men and from 14.29 in 1973 to 12.02 in 1992 for women. 
CPS to the corresponding wage data collected in the outgoing rotation group supplements of May, June, July, or August, 1979. We use this matched 1979 sample of about 35,000 observations whenever the estimation requires using the union status for $1979 .{ }^{11}$

Several other preliminary data manipulations were performed to ensure enough year to year continuity in our CPS samples. One issue is that usual weekly earnings are topcoded at $\$ 999$ from 1973 to 1985 , and at $\$ 1923$ thereafter. A relatively low value of the top code in real terms is likely to understate wage dispersion in the upper tail of the distribution. To avoid this type of bias, we use the upper tail of the 1986 distribution of wages to impute a wage distribution to the observations censored at the top code in other years. This imputation procedure is used only for years in which more than 0.5 percent of the workforce is topcoded (1981 to 1985 and 1990 to 1992). Our imputation procedure is similar to the procedure we use to estimate the effect of the minimum wage on the distribution of wages (Section 3.3).

All observations with allocated wages were eliminated from the 1979-1988 outgoing rotation group files to keep these samples comparable to the 1973-1978 samples. ${ }^{12}$ In addition, only individuals of age 16 to 65 and reporting an hourly wage from $\$ 1$ to $\$ 100$ (in 1979 dollars) were kept in the sample. The GDP deflator for personal consumption expenditures was used to convert nominal wages into 1979 dollars.

Note finally that all the estimates reported in this paper are weighted by the product of the CPS sample weights with usual hours of work. These "hoursweighted" estimates put more weight on the wages of workers who supply many hours to the labor market. This gives a better representation of the dispersion of wages for each and every hour worked in the labor market, regardless of who is supplying this hour.

Summary statistics of the CPS samples are reported in Table I. While real wages decreased for men over the 1973-1992 period, they increased for women. The workforce became increasingly more educated and nonwhite. Potential labor market experience (age-education-5) followed a U-shaped curve as the baby boom generation first entered the labor market during the 1970's and then aged during the 1980 's. Table I also indicates that while the minimum wage and

\footnotetext{
${ }^{11}$ It is also possible to obtain the union status of workers for the subsample of workers who were in an outgoing rotation group in May 1980, or 1981 since they were asked about their union status in the dual job holding supplement.

${ }^{12}$ As is well known, a significant fraction of interviewees in the CPS fail to answer questions about wages (Lillard, Smith, and Welch (1986)). While the Census Bureau used a "hot deck" procedure to replace missing wages by an allocated value in the 1979-92 outgoing rotation group files, it simply coded the wage as missing in the 1973-78 dual job holding supplements. Note also that, because of a coding error in the CPS, it is impossible to identify most workers with allocated wages from 1989 to 1992 (see Devine (1993)). This error is of little consequence for most of our analysis as we focus on the $1979-88$ period.
} 
the unionization rate were relatively stable or even increasing during the 1970's, they both fell precipitously during the 1980 's. ${ }^{13}$

\subsection{Weighted Kernel Density Estimation}

The density estimates reported in this paper are obtained by adapting the kernel density estimator introduced by Rosenblatt (1956) and Parzen (1962) to the case in which sample weights are attached to each observation. The kernel density estimate $\hat{f}_{h}$ of a univariate density $f$ based on a random sample $W_{1}, \ldots, W_{n}$ of size $n$, with weights $\theta_{1}, \ldots, \theta_{n}\left(\sum_{i} \theta_{i}=1\right)$, is

$$
\hat{f}_{h}(w)=\sum_{i=1}^{n} \frac{\theta_{i}}{h} K\left(\frac{w-W_{i}}{h}\right)
$$

where $h$ is the bandwidth and $K(\cdot)$ is the kernel function. The critical issue in kernel density estimation is the choice of bandwidth. ${ }^{14}$ In this paper, we use the plug-in method of Sheather and Jones (1991) as bandwidth selector since it does not exhibit the discretization problems associated with cross-validation methods (Silverman (1986)). All kernel density estimates presented here use the optimal bandwidth calculated with Sheather and Jones' selector. The kernel function used is Gaussian while the weights $\theta_{i}$ are the CPS sample weights multiplied by usual hours of work and normalized to sum to one. The optimal bandwidths for these "hours-weighted" density estimates range from 0.05 to 0.08 , depending on the range of the support and the sparsity of the observations. While the estimated densities become less smooth when the bandwidth becomes small relative to the optimal value, the general shape of the densities remains the same for a large range of bandwidths.

\section{ESTIMATION OF COUNTERFACTUAL DENSITIES OF WAGES}

Our procedure for decomposing changes in the density of wages is a generalization of the familiar Oaxaca decomposition of changes in means. Our decompositions are based on simple counterfactual densities such as "what would the density of wages have been in 1988 if workers' attributes, such as their union status, had remained at their 1979 level?" One methodological contribution of

\footnotetext{
${ }^{13}$ The relative constancy of the unionization rate during the 1970's masks a decline in private sector unionization that was more than offset by a steep increase in public sector unionization. Public sector unionization then remained constant while private sector unionization declined sharply during the 1980's. See Freeman and Ichniowski (1988).

${ }^{14}$ The development and comparison of optimal bandwidth selectors is a topic of continuing research. Park and Turlach (1992) conducted simulation experiments to evaluate the performance of various bandwidth selectors in terms of minimizing the Expected Integrated Square Error (EISE = $\left.E \int\left(\hat{f}_{\hat{h}}-f\right)^{2}\right)$ and the Expected Integrated Absolute Error $\left(E I A E=E \int\left|\hat{f}_{\hat{h}}-f\right|\right)$. The plug-in method of Sheather and Jones (1991) and the bandwidth factorized smoothed cross-validation of Jones, Marron, and Park (1991) were shown to be the best selectors for densities with complex structures exhibiting more than one mode.
} 
this paper is to show that the estimation of such counterfactual densities can be greatly simplified by the judicious choice of a "reweighting" function. Before formalizing our procedure, it is useful to illustrate the spirit of the procedure with an example.

Figure 2 illustrates the simulated effect of changes in the level of unionization on the 1988 density of real $\log$ wages for a subset of men with 12 years of education and 10 to 30 years of experience. Figure $2 \mathrm{a}$ shows that the 1988 density (dotted line) can be decomposed into the weighted sum of the densities of unionized and nonunionized workers. The density corresponding to the above counterfactual is obtained by replacing the relative weight of the densities of unionized workers vs. nonunionized workers of $1988(0.35)$ by that of $1979(0.47)$. The effect of changing the unionization level is then given, in Figure $2 b$, by the difference between the 1988 density (dotted line) and the counterfactual density (solid line). It is apparent that, in general, this counterfactual density is to the right of the original density, although the effect diminishes as one considers the most highly paid workers.

The reweighting scheme is easy to conceptualize in this simple example. For the cases we examine in this paper, however, a more rigorous approach is required.

\subsection{Notation}

In order to discuss our estimation procedure, it is useful to view each individual observation as a vector $(w, z, t)$ made up of a wage $w$ (which is virtually a continuous variable), a vector $z$ of individual attributes (some of which are discrete variables), and a date $t$, which will take only two values in the following comparisons. Each individual observation belongs to a joint distribution $F(w, z, t)$ of wages, individual attributes, and dates. The joint distribution of wages and attributes at one point in time is the conditional distribution $F(w, z \mid t)$. This distribution may also depend on distributional characteristics such as the

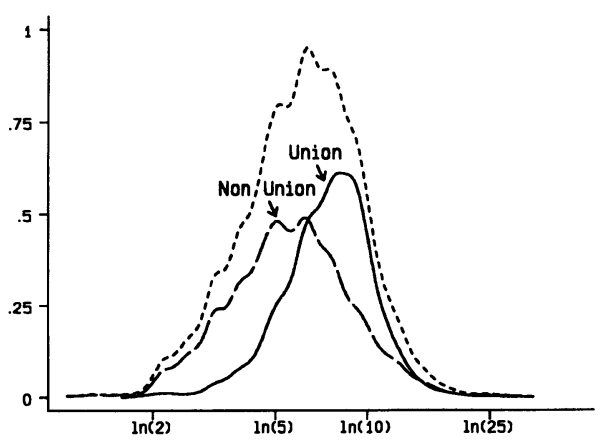

a) Densities from the union and non-union sector in 1988

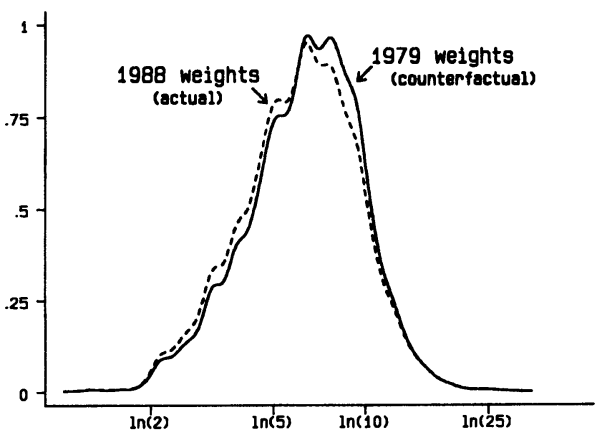

b) Weighted sum of the union and non-union densities in 1988

FIGURE 2.-An illustration of the estimation of the effect of unions for male high school graduates with 10 to 30 years of experience. 
minimum wage $m_{t}$. The density of wages at one point in time, $f_{t}(w)$, can be written as the integral of the density of wages conditional on a set of individual attributes and on a date $t_{w}, f\left(w \mid z, t_{w} ; m_{t}\right)$, over the distribution of individual attributes $F\left(z \mid t_{z}\right)$ at date $t_{z}$ :

$$
\begin{aligned}
f_{t}(w) & =\int_{z \in \Omega_{z}} d F\left(w, z \mid t_{w, z}=t ; m_{t}\right) \\
& =\int_{z \in \Omega_{z}} f\left(w \mid z, t_{w}=t ; m_{t}\right) d F\left(z \mid t_{z}=t\right) \\
& \equiv f\left(w ; t_{w}=t, t_{z}=t, m_{t}\right),
\end{aligned}
$$

where $\Omega_{z}$ is the domain of definition of the individual attributes. Since the estimation of counterfactual densities involves the combination of different "datings," the last line introduces the notation that accounts for these. For example, while $f\left(w ; t_{w}=88, t_{z}=88, m_{88}\right)$ represents the actual density of wages in $1988, f\left(w ; t_{w}=88, t_{z}=79, m_{88}\right)$ represents the density of wages that would have prevailed in 1988 had the distribution of individual attributes remained as it was in 1979.

Under the assumption that the 1988 structure of wages, which is represented by the conditional density $f\left(w \mid z, t_{w}=88 ; m_{88}\right)$, does not depend on the distribution of attributes, the hypothetical density $f\left(w ; t_{w}=88, t_{z}=79, m_{88}\right)$ is

$$
\begin{aligned}
f\left(w ; t_{w}=88, t_{z}=79, m_{88}\right) & =\int f\left(w \mid z, t_{w}=88 ; m_{88}\right) d F\left(z \mid t_{z}=79\right) \\
& \equiv \int f\left(w \mid z, t_{w}=88 ; m_{88}\right) \psi_{z}(z) d F\left(z \mid t_{z}=88\right),
\end{aligned}
$$

where the "reweighting" function $\psi_{z}(z)$ is defined as

$$
\psi_{z}(z) \equiv d F\left(z \mid t_{z}=79\right) / d F\left(z \mid t_{z}=88\right) .
$$

Calling the counterfactual density $f\left(w ; t_{w}=88, t_{z}=79, m_{88}\right)$ the "density that would have prevailed if individual attributes had remained at their 1979 level" is a misuse of language. This density should rather be called the "density that would have prevailed if individual attributes had remained at their 1979 level and workers had been paid according to the wage schedule observed in 1988," since we ignore the impact of changes in the distribution of $z$ on the structure of wages in general equilibrium.

Equation (3) shows that the counterfactual density is identical to the 1988 density except for the function $\psi_{z}(z)$. The critical point in the estimation of counterfactual densities is to recognize that they can be rewritten in terms of actual densities with the help of "reweighting" functions.

Once an estimate $\hat{\psi}_{z}(z)$ of this reweighting function is obtained (see below), it can be used to estimate the counterfactual density by weighted kernel methods. 
Thus we have

$$
\hat{f}\left(w ; t_{w}=88, t_{z}=79, m_{88}\right)=\sum_{i \in S_{88}} \frac{\theta_{i}}{h} \hat{\psi}_{z}\left(z_{i}\right) K\left(\frac{w-W_{i}}{h}\right),
$$

where $S_{88}$ is the set of indices of the 1988 sample. The difference between the actual 1988 density and this hypothetical density represents the effect of changes in the distribution of workers' attributes. The counterfactual densities corresponding to the four factors discussed earlier are illustrated, in sequence, in Figures 4 and 5. Readers interested primarily in the empirical results may wish to skip immediately to Section 5, where we expand on these and other results.

In the remainder of this section, we explain in detail how to estimate the various counterfactual densities. This includes a discussion of the economic and statistical assumptions required to make the estimation in a nonparametric setting tractable.

\subsection{Effect of Changes in Unionization and Other Attributes}

The set of individual attributes $z$ used in the empirical analysis consist of a dummy variable for the union status, $u$, and a vector $x$ of other attributes that includes experience, schooling, race, full-time or part-time status, SMSA dummy, 3 occupational categories, and 19 industry categories. Given our focus on labor market institutions, it is useful to account for $u$ and $x$ separately. First we construct the density of wages that would have prevailed if unionization, but no other attribute, had remained at its 1979 level. Then we look at what would have happened if both $u$ and $x$ had remained at their 1979 level.

Since the distribution of attributes $F\left(z \mid t_{z}=t\right)$ is the product of $F\left(u \mid x, t_{u \mid x}=t\right)$ and $F\left(x \mid t_{x}=t\right)$, equation (2) can be used to write the density of wages in 1988 as

$$
\begin{aligned}
& f\left(w ; t_{w}=88, t_{u \mid x}=88, t_{x}=88, m_{88}\right) \\
& \quad=\iint f\left(w \mid u, x, t_{w}=88 ; m_{88}\right) d F\left(u \mid x, t_{u \mid x}=88\right) d F\left(x \mid t_{x}=88\right) .
\end{aligned}
$$

Under the assumption that the conditional density $f\left(w \mid u, x, t_{w} ; m_{t}\right)$ does not depend on the unionization rate, the density that would have prevailed in 1988 if unionization, but none of the other attributes, had remained at its 1979 level can be written as a reweighted version of the 1988 density:

$$
\begin{aligned}
f\left(w ; t_{w}=88, t_{u \mid x}=79, t_{x}=88, m_{88}\right) \\
=\iint f\left(w \mid u, x, t_{w}=88 ; m_{88}\right) d F\left(u \mid x, t_{u \mid x}=79\right) d F\left(x \mid t_{x}=88\right) \\
=\iint f\left(w \mid u, x, t_{w}=88 ; m_{88}\right) \psi_{u \mid x}(u, x) d F\left(u \mid x, t_{u \mid x}=88\right) \\
\quad \times d F\left(x \mid t_{x}=88\right),
\end{aligned}
$$


where $\psi_{u \mid x}(u, x)$ is a reweighting function defined as

$$
\begin{aligned}
\psi_{u \mid x}(u, x) & \equiv d F\left(u \mid x, t_{u \mid x}=79\right) / d F\left(u \mid x, t_{u \mid x}=88\right) \\
& =u \cdot \frac{\operatorname{Pr}\left(u=1 \mid x, t_{u \mid x}=79\right)}{\operatorname{Pr}\left(u=1 \mid x, t_{u \mid x}=88\right)}+[1-u] \cdot \frac{\operatorname{Pr}\left(u=0 \mid x, t_{u \mid x}=79\right)}{\operatorname{Pr}\left(u=0 \mid x, t_{u \mid x}=88\right)},
\end{aligned}
$$

where the latter part of equation (8) is obtained by noting that, since the union status $u$ takes on only the values 0 or $1, d F\left(u \mid x, t_{u \mid x}\right)=u \operatorname{Pr}\left(u=1 \mid x, t_{u \mid x}\right)+$ $[1-u] \operatorname{Pr}\left(u=0 \mid x, t_{u \mid x}\right) .{ }^{15}$

There are two commonly cited reasons why the conditional density of wages may depend on the unionization rate: nonrandom selection and general equilibrium (or spillover) effects. While several estimators have been proposed to handle the problem of nonrandom selection, little can be done about general equilibrium effects. This has led Lewis (1986) to conclude that it is impossible to measure the "true" effect of unions on wage dispersion. As mentioned in Section 3.1, we set the more modest task of estimating the density of wages that would have prevailed if unionization had remained at its 1979 level and workers had been paid according to the union and nonunion wage schedules observed in $1988 .^{16}$

An estimate of the reweighting function $\psi_{u \mid x}(u, x)$ can be obtained by estimating the conditional probability $\operatorname{Pr}\left(u=1 \mid x, t_{u \mid x}\right)$ for $t_{u \mid x}=79$ and 88. A standard model for estimating this conditional probability is the probit model

$$
\operatorname{Pr}\left(u=1 \mid x, t_{u \mid x}=t\right)=\operatorname{Pr}\left(\epsilon>-\beta_{t}^{\prime} H(x)\right)=1-\Phi\left(-\beta_{t}^{\prime} H(x)\right),
$$

where $\Phi(\cdot)$ is the cumulative normal distribution and $H(x)$ is a vector of covariates that is a function of $x$. In this paper, the vector $H(x)$ is a low order polynomial in $x .{ }^{17}$ If $x$ took on only a limited number of values, the best $H(x)$ to use would be a full set of dummy variables indicating each possible value of $x$. In this special case, the probit model would be equivalent to a "cell-by-cell" nonparametric model.

To account for the role of remaining attributes, we consider the density of wages that would have prevailed in 1988 if the distribution of both $u$ and $x$ had

${ }^{15}$ In the example presented in Figure 2, where $x$ is fixed, the reweighting function becomes $\psi_{u}(u)=\operatorname{Pr}\left(u=1 \mid t_{u}=79\right) / \operatorname{Pr}\left(u=1 \mid t_{u}=88\right)$ if $u=1$, and $\psi_{u}(u)=\operatorname{Pr}\left(u=0 \mid t_{u}=79\right) / \operatorname{Pr}\left(u=0 \mid t_{u}=88\right)$ if $u=0$. Thus, $\psi_{u}(u)$ is equal to $0.47 / 0.35$ for union workers, and to $0.53 / 0.65$ for nonunion workers.

${ }^{16}$ In theory, we may either overstate or understate the true effect of unions by ignoring selection issues and general equilibrium effects. The results of Card (1996) suggest that we probably overstate the effect.

${ }^{17}$ The vector $H(x)$ actually consists of a gender dummy fully interacted with fifteen dummies for experience-education groups, a quartic in experience, years of education, experience and education interacted, three region dummies, eighteen industry dummies, two occupation dummies, and dummies for race, SMSA, marital status, and part-time status. 
remained as in 1979:

$$
\begin{aligned}
f\left(w ; t_{w}=88, t_{u \mid x}=79, t_{x}=79, m_{88}\right) \\
=\iint f\left(w \mid u, x, t_{w}=88 ; m_{88}\right) d F\left(u \mid x, t_{u \mid x}=79\right) d F\left(x \mid t_{x}=79\right) \\
=\iint f\left(w \mid u, x, t_{w}=88 ; m_{88}\right) \psi_{u \mid x}(u, x) \\
\quad \times d F\left(u \mid x, t_{u \mid x}=88\right) \psi_{x}(x) d F\left(x \mid t_{x}=88\right),
\end{aligned}
$$

where $\psi_{x}(x) \equiv d F\left(x \mid t_{x}=79\right) / d F\left(x \mid t_{x}=88\right)$. Applying Bayes' rule, this ratio can be written as

$$
\psi_{x}(x)=\frac{\operatorname{Pr}\left(t_{x}=79 \mid x\right)}{\operatorname{Pr}\left(t_{x}=88 \mid x\right)} \cdot \frac{\operatorname{Pr}\left(t_{x}=88\right)}{\operatorname{Pr}\left(t_{x}=79\right)} .
$$

The probability of being in period $t$, given individual attributes $x$, can once again be estimated using a probit model

$$
\operatorname{Pr}\left(t_{x}=t \mid x\right)=\operatorname{Pr}\left(\epsilon>-\beta^{\prime} H(x)\right)=1-\Phi\left(-\beta^{\prime} H(x)\right),
$$

where $\Phi(\cdot)$ and $H(x)$ are as defined above. Given that we view the two dates as the two possible events in the date space, the unconditional probability $\operatorname{Prob}\left(t_{x}=79\right)$ is equal to the weighted number of observations in 1979 divided by the weighted number of observations in both 1979 and 1988. The unconditional probability $\operatorname{Prob}\left(t_{x}=88\right)$ is defined similarly. It is thus straightforward to compute an estimate $\hat{\psi}_{x}(x)$ using equations (11) and (12).

\subsection{Effect of Changes in the Minimum Wage}

Another potential explanation for the increase in wage inequality between 1979 and 1988 is the 27 percent decline in the real value of the minimum wage. To evaluate the impact of this decline, we wish to construct a counterfactual density of wages in 1988 obtained by raising the minimum wage back to its 1979 level. Most of the research on the effects of raising the value of the minimum wage has focused on its potential disemployment effect. ${ }^{18}$ Although the potential distributional consequences of the minimum wage have long been noted (Stigler (1946)), they have received comparatively less attention and there is not established consensus on the empirical strategy for estimating these effects. ${ }^{19}$

Our analysis thus begins with a set of simple economic assumptions that are easy to implement in a nonparametric setting. For robustness, we also consider a few alternative assumptions and show that these alternative assumptions tend to

\footnotetext{
${ }^{18}$ See Brown, Gilroy, and Kohen (1982) and Card and Krueger (1995) for surveys of this research.

${ }^{19}$ Gramlich (1976) is an important early paper on this topic. More recently, the subject has been considered by Horrigan and Mincy (1993), Machin and Manning (1994), and Card and Krueger (1995).
} 
magnify the equalizing effect of the minimum wage. Our primary assumptions are therefore conservative in the sense of minimizing the effect (in absolute value) of a hypothetical increase in the minimum wage on measures of wage dispersion such as the variance of log wages. These assumptions are the following.

AsSUMPTION 1: The minimum wage has no spillover effects on the distribution of wages above the minimum wage. For any two values $m_{0}$ and $m_{1}\left(m_{0} \leq m_{1}\right)$ of the minimum wage, this implies that the conditional densities $f\left(w \mid z, t_{w} ; m_{0}\right)$ and $f\left(w \mid z, t_{w} ; m_{1}\right)$ are the same for wages above the highest value of the minimum wage $\left(m_{1}\right)$ :

$$
\left[1-I\left(w \leq m_{1}\right)\right] f\left(w \mid z, t_{w} ; m_{0}\right)=\left[1-I\left(w \leq m_{1}\right)\right] f\left(w \mid z, t_{w} ; m_{1}\right)
$$

where $I(\cdot)$ is an indicator function that takes on the value 1 if the condition in parentheses is satisfied, and 0 otherwise. Thus whenever $\left[1-I\left(w \leq m_{1}\right)\right]=1$, the wage $w$ is above the minimum wage.

Increasing the minimum wage should have positive spillover effects on the wage of skilled workers-earning more than the minimum-if these workers were substitutes for minimum wage workers. ${ }^{20}$ There is indeed evidence of small spillover effects of the minimum wage on wages just above the minimum (Grossman (1983), Katz and Krueger (1992), Card and Krueger (1994)). On the other hand, allowing for positive spillover effects on wages just above the minimum wage-but below the mean and median-would magnify the equalizing effect of the minimum wage. Assumption 1 is thus conservative.

In order to simulate a complete counterfactual density, assumptions about wages below the minimum wage have to be made. Wages observed below the minimum wage are the result of either noncoverage or noncompliance. Thus, our second primary assumption guarantees that, if the minimum wage in 1988 had remained at its 1979 level, then the distribution of 1988 wages below the 1979 minimum wage would have been similar to that of 1979 , after adjusting for differences in the composition of the labor force.

AsSUMPTION 2: The shape of the conditional density of real wages at or below the minimum wage only depends on the (real) value of the minimum wage. Therefore, for two years, $t_{0}$ and $t_{1}$, and two values of the minimum wage, $m_{0}$ and $m_{1}$ $\left(m_{0} \leq m_{1}\right)$, the shape of the conditional density $f\left(w \mid z, t_{0} ; m_{1}\right)$ that would prevail at $t_{0}$ if $m_{0}$ were raised to $m_{1}$ is proportional to the shape of the conditional density $f\left(w \mid z, t_{1} ; m_{1}\right)$ for wages at or below the highest value of the minimum wage $\left(m_{1}\right)$.

${ }^{20}$ The assumption that there is no substitution possible between these two types of workers is much stronger than the assumption of constant elasticity of substitution of Bound and Johnson (1992). 
This implies that, for wages at or below the value of the 1979 minimum wage, that is for $w$ such that $I\left(w \leq m_{79}\right)=1$, the conditional density of wages that would prevail in 1988 if the minimum wage were raised back to its 1979 level is proportional to the conditional density of wages in 1979:

$$
\begin{aligned}
I(w & \left.\leq m_{79}\right) f\left(w \mid z, t_{w}=79 ; m_{79}\right) \\
& =\psi_{w}\left(z, m_{79}\right) I\left(w \leq m_{79}\right) f\left(w \mid z, t_{w}=88 ; m_{79}\right),
\end{aligned}
$$

where $\psi_{w}\left(z, m_{79}\right)$ is a reweighting function to be specified below.

A variation on this assumption is that raising the minimum wage back to its 1979 level would not affect the part of the 1988 distribution below the lower 1988 minimum wage. Assumption 2 would still hold, however, for wages between the 1988 and the 1979 values of the minimum wage. ${ }^{21}$ A comparison of Panel (a) and (c) of Appendix Table A2 indicates that, empirically, the effect of increasing the minimum wage is larger under this alternative assumption.

\section{AsSUMPTION 3: The minimum wage has no effects on employment probabilities.}

This assumption is dictated by an emerging consensus that disemployment effects of increases in the minimum wage are relatively small (Brown, Gilroy, and Kohen (1982), Card and Krueger (1995)). Moreover, allowing for disemployment effects would cause some attrition in the lower tail of the distribution which would magnify the equalizing effect of the minimum wage. ${ }^{22}$

How we estimate the effect of the minimum wage under Assumptions 1 to 3 is more easily described with a picture. Consider the densities of wages displayed for a relatively homogeneous group of workers in 1979 (Figure 3a) and 1988 (Figure $3 b) .^{23}$ The vertical lines represent the real value of the minimum wage in 1979. Our simple estimator consists of replacing the section of the 1988 density at or below the 1979 minimum wage by the corresponding section of the 1979 density. Note that the section imputed from the 1979 density has to be scaled appropriately to make sure that the overall density still integrates to one. The

\footnotetext{
${ }^{21}$ Another possible assumption considered by Blackburn, Bloom, and Freeman (1992) is that all workers earning between the 1979 and 1988 minima would earn the 1979 minimum, while the wage of workers earning less than the 1988 minimum would increase in the same proportion as the minimum wage. Our alternative to Assumption 2 is clearly more conservative since the wage of workers earning less than the 1988 minimum does not change, while some workers earning between the 1988 and 1979 minima end up earning less than the 1979 minimum when we impute the 1979 distribution. Interestingly, Blackburn, Bloom, and Freeman (1992) also assume no disemployment effects and no spillover effects.

${ }^{22}$ In Appendix Table A2, we show that the effect of the minimum wage is indeed larger when we allow for a disemployment elasticity of 0.15 (Brown, Gilroy, and Kohen (1982)). Similar results would be obtained if the minimum wage had no effects on the number of workers employed but had a negative effect on the number of hours worked by minimum wage workers.

${ }^{23}$ The densities in Figure 3 were estimated for women with 12 years of education or less, and with less than 20 years of experience. The apparent spillover effect of the minimum wage in Figure $4 \mathrm{c}$ is in fact a result of the smoothing.
} 


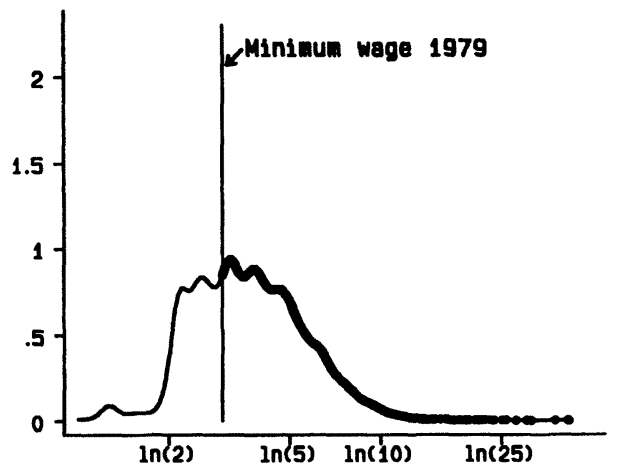

a) Density Estimate of Real Log Wages in 1988

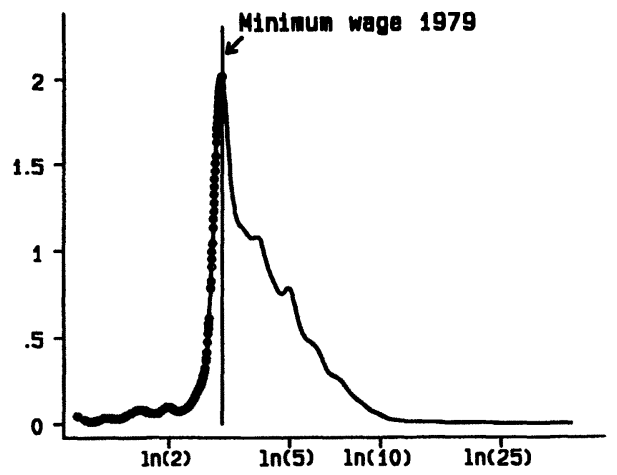

b) Density Estimate of Aeal Log Wages in 1979

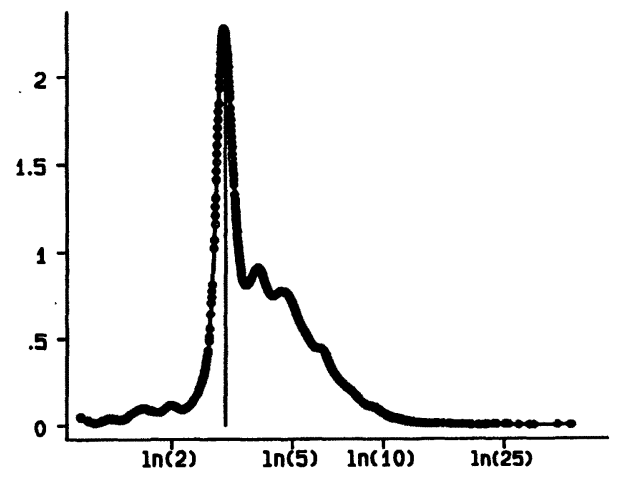

c) Density Estinate of Real Log Wages in 1988 Adjusted for .1979's Minimun Wage

FIGURE 3.-An illustration of the estimation of the effect of the minimum wage for female high school dropouts with 20 years or less of experience. 
resulting 1988 density with the minimum wage at its 1979 level is represented in Figure $3 \mathrm{c}$. The effect of the minimum wage on the density of wages is the difference between Figure $3 \mathrm{a}$ and $3 \mathrm{c}$.

More formally, we construct a 1988 conditional density with the minimum wage at its 1979 value by selecting the part of the 1988 density above $m_{79}$ and the part of the 1979 density at or below $m_{79}$ with an indicator function. We also premultiply the 1979 density by a reweighting function $\psi_{w}\left(z, m_{79}\right)$ to make sure the overall density integrates to one:

$$
\begin{aligned}
f\left(w \mid z, t_{w}=88 ; m_{79}\right)= & I\left(w \leq m_{79}\right) \psi_{w}\left(z, m_{79}\right) f\left(w \mid z, t_{w}=79 ; m_{79}\right) \\
& +\left[1-I\left(w \leq m_{79}\right)\right] f\left(w \mid z, t_{w}=88 ; m_{88}\right),
\end{aligned}
$$

where

$$
\psi_{w}\left(z, m_{79}\right)=\frac{\operatorname{Pr}\left(w \leq m_{79} \mid z, t_{w}=88\right)}{\operatorname{Pr}\left(w \leq m_{79} \mid z, t_{w}=79\right)} .
$$

To obtain the effect of the minimum wage on the overall distribution of wages in 1988 , it is necessary to integrate the conditional density in equation (15) over the distribution of attributes:

$$
\begin{aligned}
f\left(w ; t_{w}=88, t_{z}=88, m_{79}\right) \\
=\int f\left(w \mid z, t_{w}=88 ; m_{79}\right) d F\left(z \mid t_{z}=88\right) \\
=\int I\left(w \leq m_{79}\right) \psi_{w}\left(z, m_{79}\right) f\left(w \mid z, t_{w}=79 ; m_{79}\right) d F\left(z \mid t_{z}=88\right) \\
\quad+\left[1-I\left(w \leq m_{79}\right)\right] f\left(w \mid z, t_{w}=88 ; m_{88}\right) d F\left(z \mid t_{z}=88\right) \\
=\int I\left(w \leq m_{79}\right) \psi_{w}\left(z, m_{79}\right) f\left(w \mid z, t_{w}=79 ; m_{79}\right) \psi_{z}(z)^{-1} d F\left(z \mid t_{z}=79\right) \\
\quad+\left[1-I\left(w \leq m_{79}\right)\right] f\left(w \mid z, t_{w}=88 ; m_{88}\right) d F\left(z \mid t_{z}=88\right),
\end{aligned}
$$

where $\psi_{w}\left(z, m_{79}\right)$ is as defined in equation (16), and where

$$
\psi_{z}(z)^{-1}=\frac{\operatorname{Pr}\left(t_{z}=88 \mid z\right)}{\operatorname{Pr}\left(t_{z}=79 \mid z\right)} \cdot \frac{\operatorname{Pr}\left(t_{z}=79\right)}{\operatorname{Pr}\left(t_{z}=88\right)} .
$$

After applying Bayes' rule, the product of the two reweighting functions simplifies to

$$
\begin{aligned}
\psi\left(z, m_{79}\right) & \equiv \psi_{w}\left(z, m_{79}\right) \cdot \psi_{z}(z)^{-1} \\
& =\frac{\operatorname{Pr}\left(t_{w}=88 \mid z, w \leq m_{79}\right)}{\operatorname{Pr}\left(t_{w}=79 \mid z, w \leq m_{79}\right)} \cdot \frac{\operatorname{Pr}\left(t_{z}=79\right)}{\operatorname{Pr}\left(t_{z}=88\right)} .
\end{aligned}
$$

The probability of being at date $t$, given certain individual attributes and a wage below the 1979 minimum wage, can be estimated using a probit model

$$
\operatorname{Pr}\left(t_{w}=t \mid z, w \leq m_{79}\right)=\operatorname{Pr}\left(\epsilon>-\beta^{\prime} H(z)\right)=1-\Phi\left(-\beta^{\prime} H(z)\right) .
$$


In practice, this probit model is estimated by pooling observations from the 1979 and 1988 samples that have real wages smaller or equal to the 1979 real minimum wage. ${ }^{24}$

\subsection{Effect of Changes in Supply and Demand}

The effects that we have described to this point have been primarily "institutional." They have ignored the supply and demand conditions that are at the heart of many discussions on the causes of changes in the wage structure. One difficulty with supply and demand considerations is that they do not readily fit into our distributional framework. Standard measures of supply and demand are useful for understanding wage dispersion between skill categories of workers, but they are not well suited for understanding residual wage dispersion within these categories.

Despite this caveat, we incorporate standard measures of supply and demand into our framework for two reasons. First, we wish to compare our findings on the relative importance of institutional factors with the rest of the literature that has focused heavily on supply and demand. We also want to ensure that we are not overstating the importance of institutional factors by ignoring supply and demand considerations.

The estimation of the effect of supply and demand on the structure of wages has been well described by Bound and Johnson (1992) and Katz and Murphy (1992), among others. We follow directly the estimation procedure proposed by Bound and Johnson as we are analyzing the same CPS data over the same time period. Accordingly, we divide the workforce into 32 experience-educationgender cells and construct measures of supply $\left(N_{j t}\right)$ and demand $\left(D_{j t}\right)$ for each cell $j$.

Under the assumption that the production function in each industry is CES (constant elasticity of substitution), linear regression methods can be used to estimate the shift, $\Delta \hat{w}_{j}$, in the mean cell wage due to changes in supply and demand. The regression is estimated in second differences (1979-88 change minus 1973-79 change) to eliminate cell-specific linear trends due, for example, to technological change. The supply variable $N_{j t}$ is defined as the share of the total workforce in cell $j$. The demand variable $D_{j t}$ is a "fixed-coefficient manpower requirements index" that reflects between-sector shifts in relative labor demands. ${ }^{25}$ Two vectors of distributional characteristics $d_{t}=$

\footnotetext{
${ }^{24}$ In the estimation, we use the log of $\$ 3.00$ instead of the minimum wage of $\$ 2.90$ as the value of $m_{79}$ (in 1979 dollars). This choice is driven by the abnormal concentration of workers at $\$ 3.00$ in 1979 which suggests either small spillover effects of the minimum wage or misreporting. The sensitivity of our results to this choice is investigated in Appendix Table A2.

${ }^{25}$ Following Bound and Johnson (1992), we use a measure of demand shifts that nets-out supply shifts. See equations (A10) to (A12) in the Appendix to their paper. Unlike Bound and Johnson, however, we do not constrain $N_{j t}$ and $D_{j t}$ to have equal and opposite coefficients, as predicted by the theory. We just let $N_{j t}$ and $D_{j t}$ explain as much as they can of changes in relative wages. The details of the construction of the supply and demand indices are available from the authors upon request.
} 
(ln $\left.D_{1, t}, \ldots, \ln D_{32, t}\right)$ and $n_{t}=\left(\ln N_{1, t}, \ldots, \ln N_{32, t}\right)$ summarize supply and demand conditions. Expanding the list of distributional characteristics to include $d_{t}$ and $n_{t}$, the conditional density of wages in 1988 becomes $f\left(w \mid z, t_{w}=\right.$ $\left.88 ; m_{88}, d_{88}, n_{88}\right)$. The conditional density of wages that would have prevailed if supply and demand conditions had remained at their 1979 level thus can be written as

$$
f\left(w \mid z, t_{w}=88 ; m_{88}, d_{79}, n_{79}\right)=f\left(w-\Delta \hat{w}_{j} \mid z, t_{w}=88 ; m_{88}, d_{88}, n_{88}\right) .
$$

The overall effect of supply and demand shocks is the difference between the 1988 density of wages and the hypothetical density obtained by integrating equation (21) over the distribution of individual attributes $z$ :

$$
\begin{aligned}
f\left(w ; t_{w}=88, t_{z}=88, m_{88}, d_{79}, n_{79}\right) \\
\quad=\int f\left(w-\Delta \hat{w}_{j} \mid z, t_{w}=88 ; m_{88}, d_{88}, n_{88}\right) d F\left(z \mid t_{z}=88\right) .
\end{aligned}
$$

\section{DECOMPOSITION OF CHANGES IN DENSITIES}

\subsection{Sequential Decomposition}

Our main analysis of changes in the density of wages between 1979 and 1988 is based on the following sequential decomposition:

$$
\begin{gathered}
f_{88}(w)-f_{79}(w) \\
=\left[f\left(w ; t_{w}=88, t_{z}=88, m_{88}\right)-f\left(w ; t_{w}=88, t_{z}=88, m_{79}\right)\right] \\
+\left[f\left(w ; t_{w}=88, t_{u \mid x}=88, t_{x}=88, m_{79}\right)\right. \\
\left.-f\left(w ; t_{w}=88, t_{u \mid x}=79, t_{x}=88, m_{79}\right)\right] \\
+\left[f\left(w ; t_{w}=88, t_{u \mid x}=79, t_{x}=88, m_{79}\right)\right. \\
\left.-f\left(w ; t_{w}=88, t_{u \mid x}=79, t_{x}=79, m_{79}\right)\right] \\
+\left[f\left(w ; t_{w}=88, t_{z}=79, m_{79}, d_{88}, n_{88}\right)\right. \\
\left.\quad-f\left(w ; t_{w}=88, t_{z}=79, m_{79}, d_{79}, n_{79}\right)\right] \\
+\left[f\left(w ; t_{w}=88, t_{z}=79, m_{79}, d_{79}, n_{79}\right)\right. \\
\left.-f\left(w ; t_{w}=79, t_{z}=79, m_{79}, d_{79}, n_{79}\right)\right]
\end{gathered}
$$

where we have omitted the distributional factors $d_{88}$ and $n_{88}$ in the first three components of the decomposition to simplify the notation. The five components of equation (23) represent the "effect" of the minimum wage, unionization, other attributes, supply and demand, and residual factors, respectively.

The decomposition in equation (23) is sequential to ensure that the change in densities between 1979 and 1988 is exactly equal to the sum of the components corresponding to the factors we analyze. One drawback of sequential decompo- 
sitions is that the "effect" of a given factor generally depends on the order of the decomposition. We will thus consider a decomposition in reverse order to ensure that we are not overstating the impact of labor market institutions - the minimum wage and unions - by considering them first. We next show how the estimation methods developed in Section 3 can be adapted to estimate the various elements of decomposition (23).

\subsection{Decomposition of Densities with Weighted Kernel Estimators}

To simplify the notation, we use a subscript $i$ to label the reweighting functions corresponding to observation $i$. The weighted kernel density estimates of all counterfactual densities considered in Section 3 are special cases of the following equation:

$$
\hat{f_{h}}(w)=\sum_{i \in S} \frac{\theta_{i} \hat{\Psi}_{i}}{h} K\left(\frac{w-\omega_{i}}{h}\right),
$$

where $\Psi_{i}$ denotes the weighting function, $\omega_{i}$ denotes the wage of interest (either $\omega_{i}=W_{i}$ or $\omega_{i}=W_{i}-\Delta W_{i}$ ), and $S$ is the set of indices of the appropriate sample.

Estimates of the counterfactual densities in decomposition (23) are obtained by substituting in equation (24) combinations of the reweighting functions described in Section 3. These combinations of reweighting functions are summarized in Table II. The first panel of Table II displays the $\Psi$ functions corresponding to the sequential decomposition (23). For example, the weights used to estimate the density $f\left(w ; t_{w}=88, t_{u \mid x}=79, t_{x}=79 ; m_{79}\right)$, which account for changes in the minimum wage, in the unionization rate, and in other individual attributes, are displayed in column 3 of this first panel. The estimated density is obtained by setting $\Psi$ to $\psi \psi_{u \mid x} \psi_{x}$ for the 1979 observations at or below the 1979 minimum wage, and to $\psi_{u \mid x} \psi_{x}$ for the 1988 observations above the 1979 minimum, and to zero for 1988 observations at or below the 1979 minimum. This product of reweighting functions is obtained by sequentially applying the reweighting function associated with the minimum wage (19), the function associated with unionization (8), and that of other attributes (11). ${ }^{26}$

Note that the reweighting function associated with changes in the minimum wage, $\psi$, is replaced by $\psi^{\prime}$ when supply and demand factors are also taken into account:

$$
\psi^{\prime}\left(z, m_{79}\right)=\frac{\operatorname{Pr}\left(t_{w}=88 \mid z, \omega \leq m_{79}\right)}{\operatorname{Pr}\left(t_{w}=79 \mid z, \omega \leq m_{79}\right)} \cdot \frac{\operatorname{Pr}\left(t_{z}=79\right)}{\operatorname{Pr}\left(t_{z}=88\right)},
$$

where $\omega=w$ in 1979 and $\omega=w-\Delta w_{j}$ in 1988. This alternative weighting scheme is used since only workers whose 1988 wage would have been below the

\footnotetext{
${ }^{26}$ Equation (10) provides a formal example of how the reweighting function associated with two factors (unionization and other attributes) can be written as the product of the reweighting functions associated with each individual factor $\left(\psi_{x}(x)\right.$ and $\left.\psi_{u \mid x}(u, x)\right)$.
} 
TABLE II

Weights USED IN DENSITY DECOMPOSITION

\begin{tabular}{|c|c|c|c|c|c|}
\hline \multirow{3}{*}{\multicolumn{2}{|c|}{ Primary Order: }} & \multirow{2}{*}{\multicolumn{4}{|c|}{$\begin{array}{l}\text { (2) } \\
\text { Factors held at their } 1979 \text { level }\end{array}$}} \\
\hline & & & & & \\
\hline & & Minimum wage & (1) + Unions & $\begin{array}{l}\text { (2) }+ \text { Individual } \\
\text { Attributes }\end{array}$ & $\begin{array}{l}\text { (3) + Supply } \\
\text { and Demand }\end{array}$ \\
\hline \multicolumn{2}{|c|}{$\begin{array}{r}\text { Counterfactual densities } \\
f\left(w ; t_{w}, t_{u \mid x}, t_{x}, m_{t}, d_{t}, n_{t}\right) \\
\text { Year }\end{array}$} & $\begin{array}{c}t_{u \mid x}=88, t_{x}=88 \\
m_{79}, m_{88}, n_{88}\end{array}$ & $\begin{array}{c}t_{u \mid x}=79, t_{x}=88 \\
m_{79}, d_{88}, n_{88}\end{array}$ & $\begin{array}{c}t_{u \mid x}=79, t_{x}=79 \\
m_{79}, d_{88}, n_{88}\end{array}$ & $\begin{array}{c}t_{u \mid x}=79, t_{x}=79 \\
m_{79}, d_{79}, n_{79}\end{array}$ \\
\hline \multirow{3}{*}{1988} & $w \leq m_{79}$ & $\psi$ & $\psi \psi_{u \mid x}$ & $\psi \psi_{u \mid x} \psi_{x}$ & $\psi^{\prime} \psi_{u \mid x} \psi_{x}$ \\
\hline & $w \leq m_{79}$ & 0 & 0 & 0 & - \\
\hline & $w>m_{79}$ & 1 & $\psi_{u \mid x}$ & $\psi_{u \mid x} \psi_{x}$ & 一 \\
\hline \multirow[t]{2}{*}{1988} & $w-\Delta \hat{w}_{j} \leq m_{79}$ & - & - & - & 0 \\
\hline & $w-\Delta \hat{w}_{j}>m_{79}$ & - & - & 一 & $\psi_{u \mid x} \psi_{x}$ \\
\hline \multicolumn{2}{|c|}{ Reverse Order: } & $\begin{array}{l}\text { Supply and } \\
\text { Demand }\end{array}$ & $\begin{array}{l}\text { (1) + Individual } \\
\text { Attributes }\end{array}$ & (2) + Unions & $\begin{array}{l}\text { (3) }+\underset{\text { Minimum }}{\text { Wage }} \\
\text { Wat }\end{array}$ \\
\hline \multicolumn{2}{|c|}{$\begin{array}{l}\text { Counterfactual densities } \\
f\left(w ; t_{w}, t_{x \mid u}, t_{u}, m_{t}, d_{t}, n_{t}\right) \\
\text { Year }\end{array}$} & $\begin{array}{c}t_{x \mid u}=88, t_{u}=88 \\
m_{88}, d_{79}, n_{79}\end{array}$ & $\begin{array}{c}t_{x \mid u}=79, t_{u}=88 \\
m_{88}, d_{79}, n_{79}\end{array}$ & $\begin{array}{c}t_{x \mid u}=79, t_{u}=79 \\
m_{88}, d_{79}, n_{79}\end{array}$ & $\begin{array}{c}t_{x \mid u}=79, t_{u}=79 \\
m_{79}, d_{79}, n_{79}\end{array}$ \\
\hline 1979 & $w \leq m_{79}$ & 0 & 0 & 0 & $\psi^{\prime} \psi_{x \mid u} \psi_{u}$ \\
\hline \multirow[t]{2}{*}{1988} & $w \leq m_{79}$ & 一 & 一 & 一 & - \\
\hline & $w>m_{79}$ & - & - & - & 一 \\
\hline \multirow[t]{2}{*}{1988} & $w-\Delta \hat{w}_{j} \leq m_{79}$ & 1 & $\psi_{x \mid u}$ & $\psi_{x \mid u} \psi_{u}$ & 0 \\
\hline & $w-\Delta \hat{w}_{j}>m_{79}$ & 1 & $\psi_{x \mid u}$ & $\psi_{x \mid u} \psi_{u}$ & $\psi_{x \mid u} \psi_{u}$ \\
\hline
\end{tabular}

Note: The weighting functions $\psi, \psi_{u \mid x}, \psi_{x}, \psi^{\prime}, \psi_{x \mid u}$ and $\psi_{u}$ are defined by equations (19), (8), (11), (25), (27), and (26), respectively.

1979 minimum wage, if supply and demand conditions had remained at their 1979 level, should be affected by switching the minimum wage back to its 1979 level.

To perform the sequential decomposition in reverse order, different weighting functions are used; they are displayed in the second panel of Table II. The reweighting functions $\psi_{x \mid u}$ and $\psi_{u}$ are introduced since the effect of other individual attributes is considered before the effect of unions. These two reweighting functions are derived by applying the procedure described in Section 3.2 in reverse order. For example, $\psi_{u}(u)$ is given by

$$
\psi_{u}(u) \equiv \frac{d F\left(u \mid t_{u}=79\right)}{d F\left(u \mid t_{u}=88\right)}=\frac{\operatorname{Pr}\left(t_{u}=79 \mid u\right)}{\operatorname{Pr}\left(t_{u}=88 \mid u\right)} \cdot \frac{\operatorname{Pr}\left(t_{u}=88\right)}{\operatorname{Pr}\left(t_{u}=79\right)}
$$

The estimate $\hat{\psi}_{u}(u)$ is thus a simple function of the unionization rates in 1979 and 1988.

Since $F(z) \equiv F(u, x)=F(u \mid x) F(x)=F(x \mid u) F(u)$, and since the reweighting function $\psi_{z}(z)$ is the ratio $d F\left(z \mid t_{z}=79\right) / d F\left(z \mid t_{z}=88\right)$, it can be written either as the product of $\psi_{u \mid x}(u, x)$ and $\psi_{x}(x)$, or as the product of $\psi_{x \mid u}(u, x)$ and $\psi_{u}(u)$. This property can be used to estimate $\psi_{x \mid u}(u, x)$ as

$$
\hat{\psi}_{x \mid u}(u, x)=\hat{\psi}_{u \mid x}(u, x) \hat{\psi}_{x}(x) / \hat{\psi}_{u}(u) .
$$


One important advantage of this estimator is that it constrains the products $\hat{\psi}_{u \mid x}(u, x) \cdot \hat{\psi}_{x}(x)$ and $\hat{\psi}_{x \mid u}(u, x) \cdot \hat{\psi}_{u}(u)$ to be equal. As a consequence, the estimate of the density that would have prevailed if both unionization and other attributes had remained at their 1979 level is invariant to the order of the decomposition. This implies that residual changes in densities are also invariant to the order of the decomposition.

\section{ACCOUNTING FOR CHANGES IN THE DENSITY OF WAGES 1979-88}

\subsection{Estimated Effects of Explanatory Factors on the Density of Wages}

We plot the weighted kernel estimates of the counterfactual densities in decomposition (23) in Figure 4 for men and in Figure 5 for women. The actual 1988 (solid line) and 1979 (dotted line) densities are superimposed in panel (a) of both figures. This shows the raw differences to be explained. For each of the explanatory factors considered, we use the following convention: we report the density obtained by holding the factor at its 1988 value with a solid line, and the density obtained by holding the factor at its 1979 value with a dotted line. The difference between the two lines represents the effect of changes in the explanatory factor on the density of wages.

The solid line in Figure $4 \mathrm{~b}$ is the 1988 density of wages $f\left(w ; t_{w}=88, t_{z}=\right.$ $\left.88, m_{88}\right)$ while the dotted line represents $f\left(w ; t_{w}=88, t_{z}=88, m_{79}\right)$. The influence of the minimum wage on the distribution of wages is clearly seen. There is more mass at the bottom of the wage distribution in 1988 (at and slightly above two dollars (1979\$)) than if the minimum wage had remained at its 1979 level. This is true for both men and women (Figure 5b).

The estimated densities with the unionization rate at its 1979 and 1988 level for men and women are presented in Figures $4 \mathrm{c}$ and $5 \mathrm{c}$ respectively. Figure $4 \mathrm{c}$ shows that changes in unionization had a substantial effect on the distribution of men's wages. The decline in unionization between 1979 and 1988 contributed to the decline of the "middle" of the distribution and the fattening of the lower tail of the distribution.

The estimated densities corresponding to changes in individual attributes other than unionization are shown in Figure $4 \mathrm{~d}$ for men and Figure $5 \mathrm{~d}$ for women. The densities with the 1979 distribution of attributes, $f\left(w ; t_{w}=88, t_{u \mid x}=\right.$ $79, t_{x}=79, m_{79}$ ) (dotted line), qualitatively look like translations to the left of the densities with the 1988 distribution of attributes (solid line). This suggests there was an upgrade in attributes or "skills" between 1979 and 1988. It is consistent with secular increases in the average number of years of schooling of workers.

Using the same convention as for the other factors, the density estimates corresponding to changes in supply and demand are reported in Figure $4 \mathrm{e}$ for men and in Figure 5e for women. Finally, panel (f) of Figures 4 and 5 superimposes the counterfactual density (solid line) that accounts for all four factors, and the 1979 density (dotted line). Discrepancies between the two lines reflect residual or unexplained changes. 

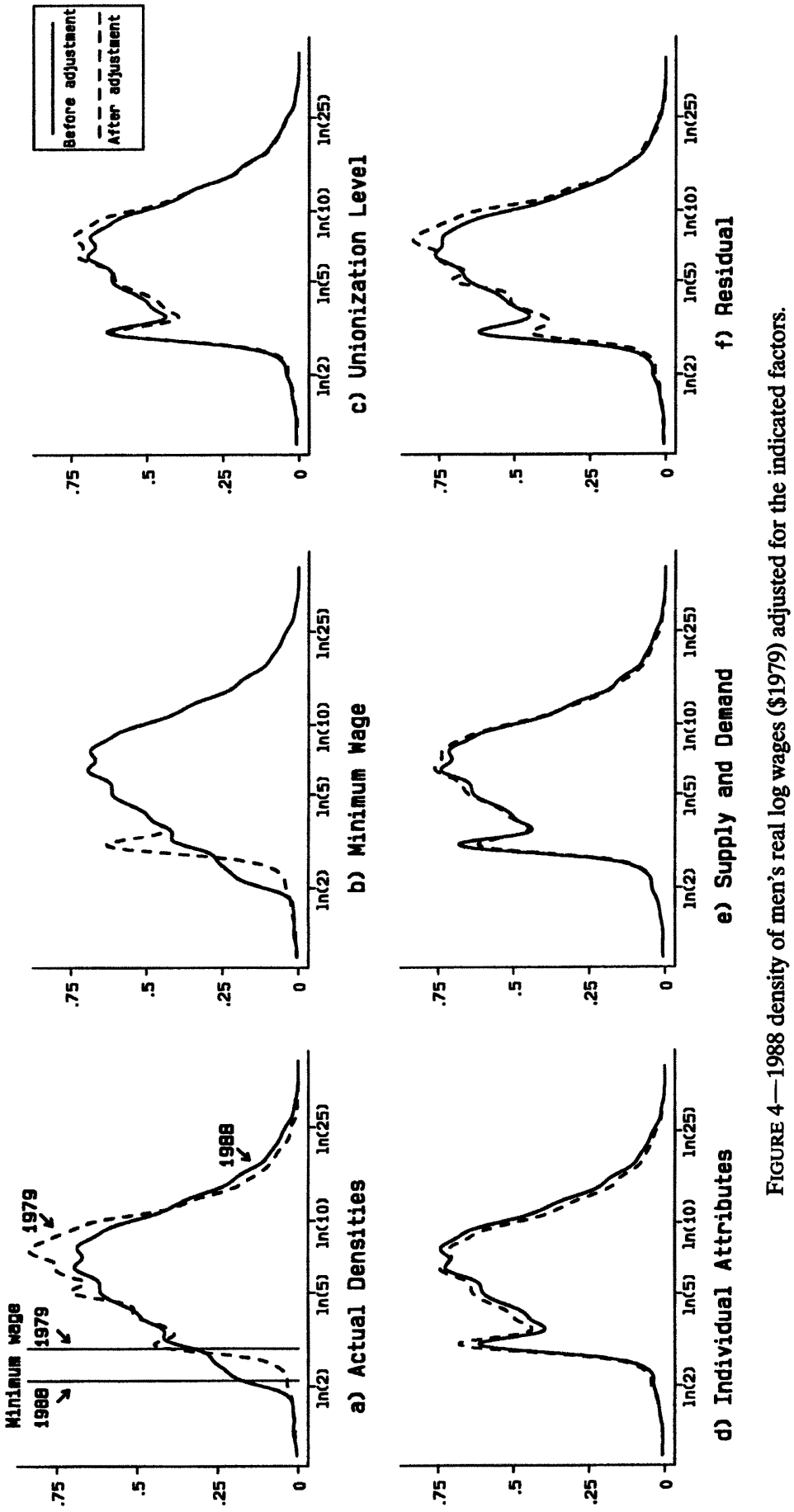

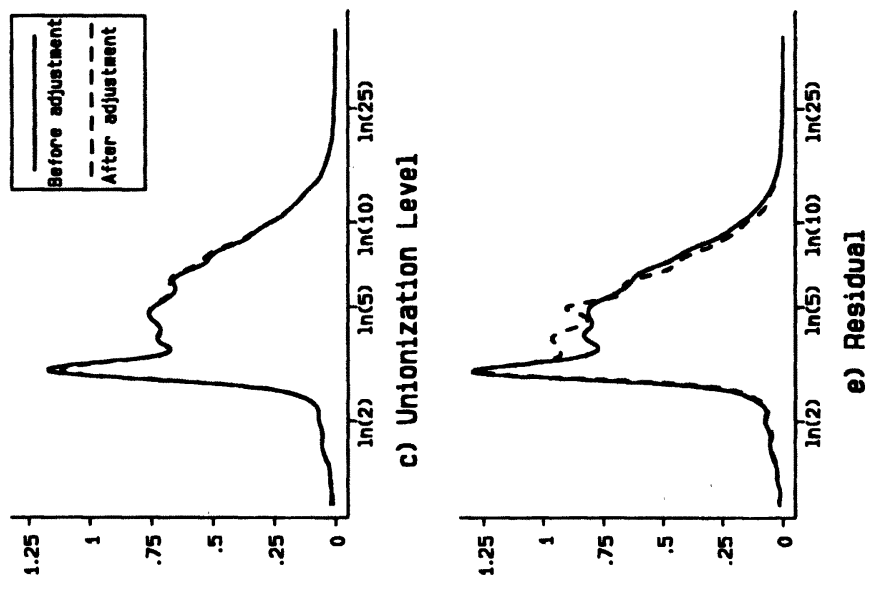

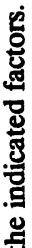
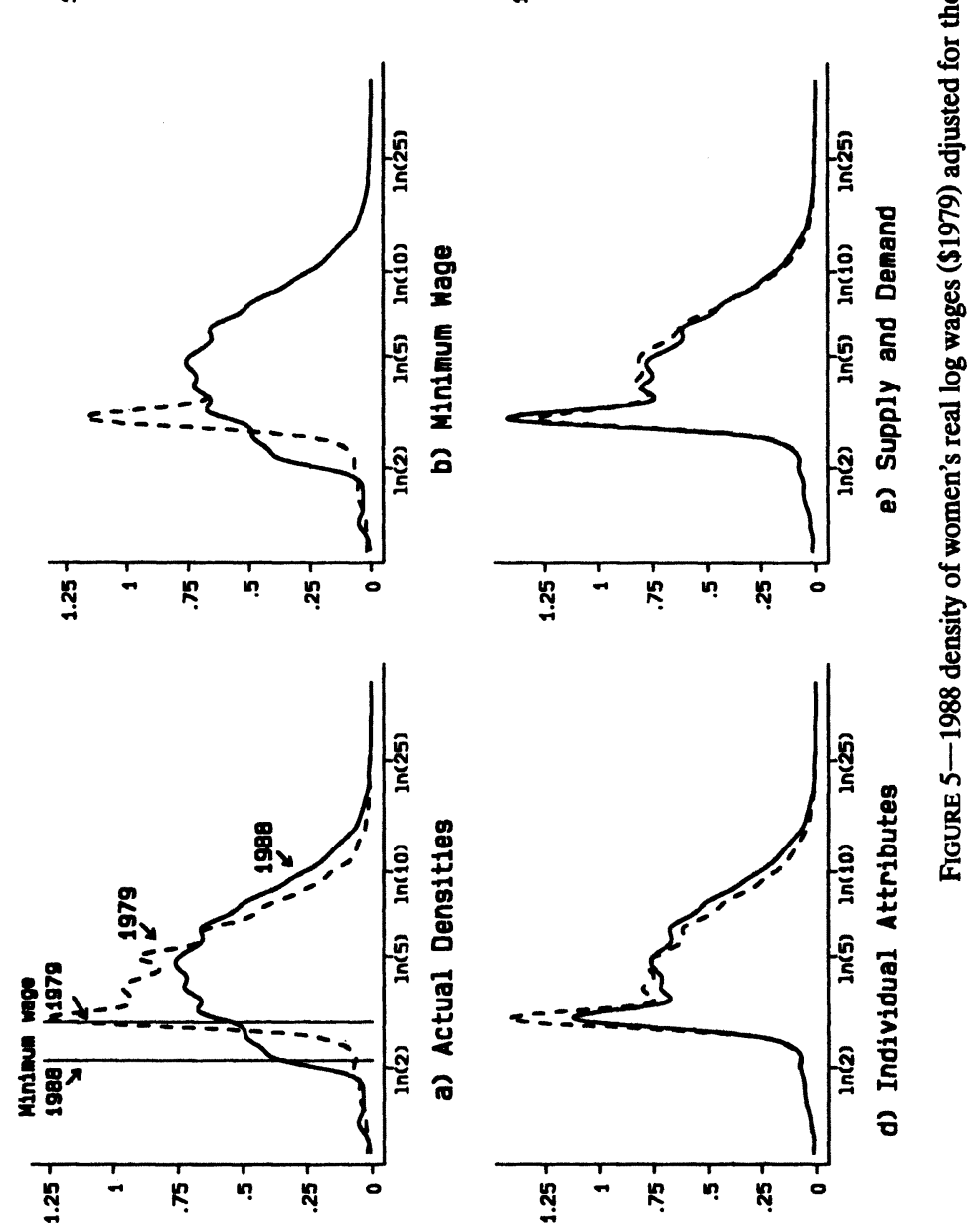


\subsection{Changes in Densities}

A clearer illustration of the contribution of the different explanatory factors is obtained by looking at the changes in densities that cannot be explained after accounting for the effect of each specific factor. These changes in densities are obtained by plotting the difference between each counterfactual density and the 1979 density. When viewed this way, the goal of the decomposition exercise is to get a "flat line" once all the factors have been accounted for.

Looking explicitly at the difference between two densities also provides a complete description of changes in the distribution of wages. For example, a mean-preserving spread of the distribution could result in a positive density difference in the tails of the distribution and in a negative density difference in the "middle" of the distribution. By contrast, measures like the variance, the 10-90 differential, or the Gini coefficient only summarize differences between two distributions with a single number. When looked at in isolation, they fail to indicate the region of the wage distribution in which most of the changes are occurring. Note also that the difference between the 1979 and the 1988 densities is not very smooth, which reduces its "visual impact." The differences in densities presented in Figures 6 and 7 were thus further smoothed using a Gaussian kernel and a bandwidth of 0.07 .

The changes in densities are displayed in Figure 6 for men and in Figure 7 for women. The vertical line marks the location of the 1979 minimum wage. Figures 6a and 7a display our estimates of the difference between the density of wages in 1988 and 1979. One of the most important feature of the difference between the two periods is the additional mass in the 1988 distribution at wages below the 1979 minimum. In Figures $6 \mathrm{~b}$ and $7 \mathrm{~b}$, we remove changes associated with the fall in the minimum wage. For men, the difference between the two densities at values below the 1979 minimum falls considerably, the tall "hump" of Figure $6 \mathrm{a}$ shifts to the right in Figure $6 \mathrm{~b}$. The results are even more striking for women. As Figure $7 \mathrm{~b}$ makes clear, the single most important cause of changes in the distribution of women's wages was the decline in the minimum wage. As it turns out, there is considerable difference between the two densities in the area immediately to the right of the 1979 minimum. This indicates the possibility of additional spillover effects of minimum wage legislation.

Next we remove changes attributable to changes in unionization in Figures $6 \mathrm{c}$ and $7 \mathrm{c}$. In the case of men, the 39 percent decrease in the unionization rate (Table I) played a significant role in explaining the clear collapse of the middle of the distribution of wages. This is easily explained by the fact that relatively unskilled workers benefit the most from unionization which moves them toward the "middle" of the wage distribution. As unionization declines, these workers slide back toward the lower tail of the distribution. By contrast, a comparison of Figures $7 \mathrm{~b}$ and $7 \mathrm{c}$ indicates that changes in unionization had a negligible effect on the distribution of women's wages. This result is consistent with the fact that the unionization rate did not decline very much for women (Table I) and that 


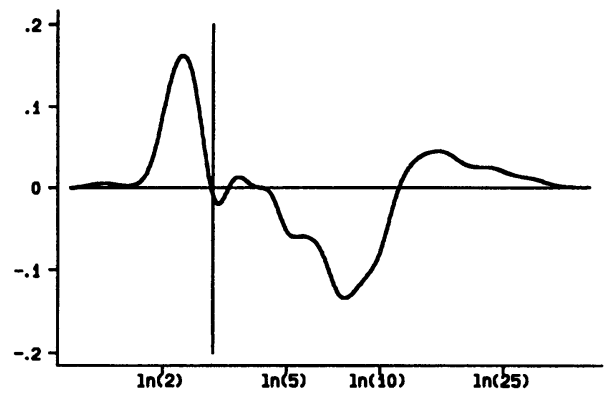

a) Actual Difference

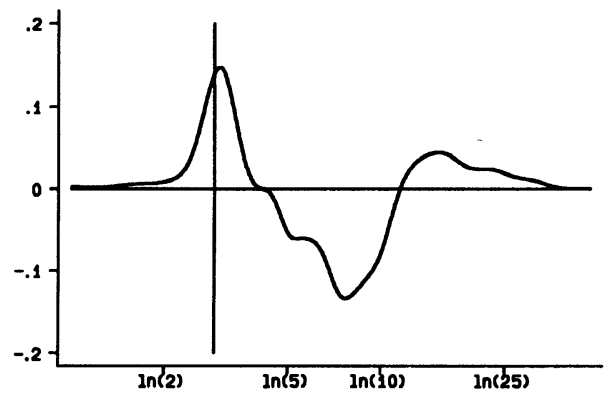

b) Minimum Wage

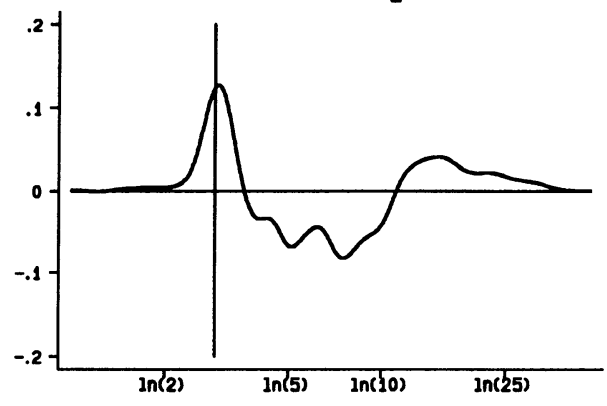

c) Unionization Level and b)

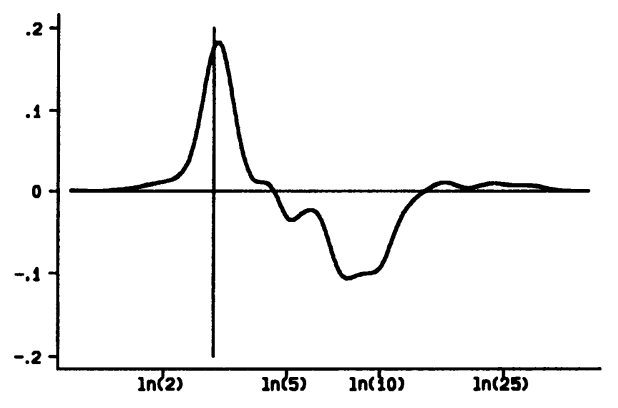

d) Individual Attributes and c)

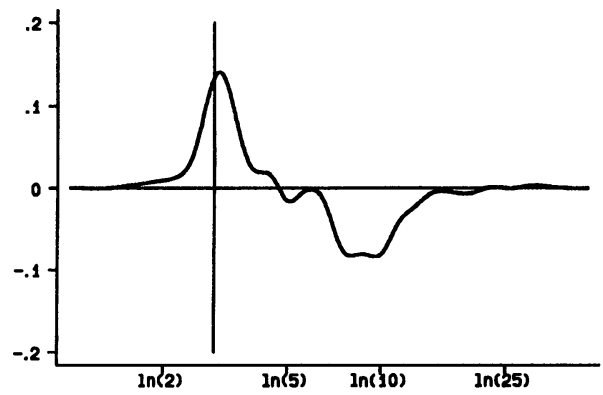

e) Supply and Demand and d)

FIGURE 6.-Smoothed differences between the 1988 density adjusted for indicated factors and the 1979 density for men.

unions generally have little impact on women's wage inequality (see Lemieux (1993)).

Over the period, the samples grew slightly older, and slightly more educated. The effects of this change can be seen in Figures $6 \mathrm{~d}$ and $7 \mathrm{~d}$. While changes in the distribution of individual attributes almost completely explain the difference between the two densities in the upper tail, they exacerbate the difference between the two densities in the lower tail. As shown in Figure 6e and 7e, changes in supply and demand reduce the remaining difference between the two 

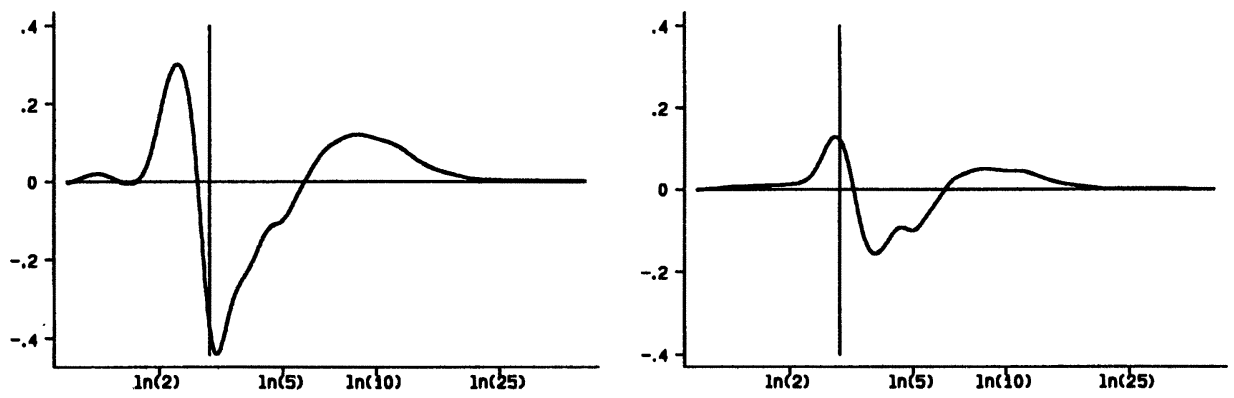

a) Actual Difference

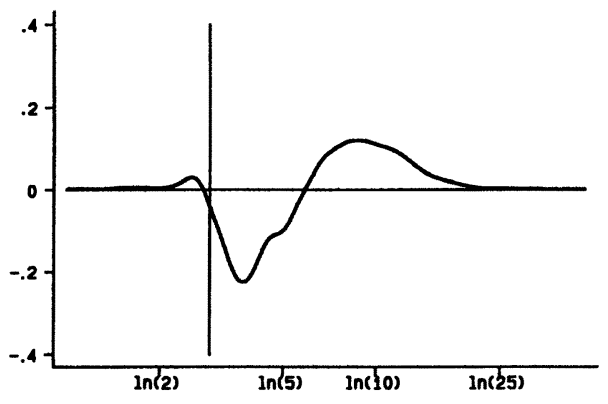

d) Individual Attributes and c)

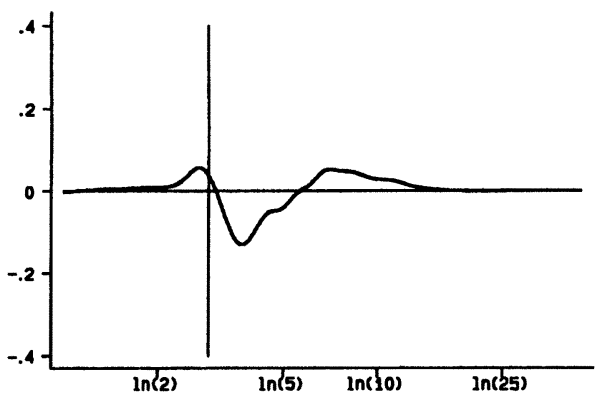

b) Minimum Wage

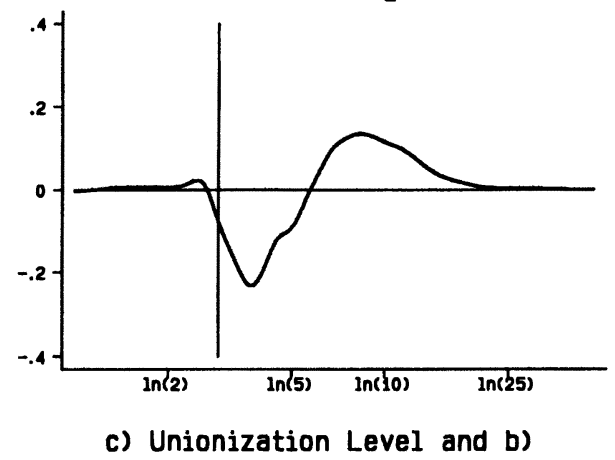

e) Supply and Demand and d)

FIGURE 7.-Smoothed differences between the 1988 density adjusted for indicated factors and the 1979 density for women.

densities everywhere. These figures show that supply and demand conditions affected workers in ways that are consistent with the well documented increase in returns to skill. For both men and women, changes in supply and demand conditions contributed to a fattening of the lower and upper tails and to a decline of the "middle" of the distribution. Figures $6 \mathrm{e}$ and $7 \mathrm{e}$ show the remaining unexplained differences. 


\subsection{Quantitative Measures}

By way of comparison with the rest of the literature and to provide some numerical values for the graphical changes documented in the previous subsections, it is useful to compute a few summary measures, such as wage differentials and Gini coefficients, as well as a measure of the divergence between the densities. Computing these measures is straightforward once the density of wages has been estimated.

For example, the 10th percentile of the estimated density of wages for 1988, $w_{.1}$, is such that

$$
\int_{0}^{w} \cdot \hat{f}_{88}(w) d w=0.10
$$

while the 90 th percentile, $w_{.9}$, is such that

$$
\int_{0}^{w \cdot 9} \hat{f}_{88}(w) d w=0.90
$$

since $w \geq 0$. The $10-90$ wage differential is simply $w_{.9}-w_{.1}$. The $1979-88$ change in the 10-90 wage differential is obtained by computing similar statistics from the estimated density for 1979 .

It is also easy to derive other inequality measures. Among the most widely used are Theil's entropy coefficient and the Gini coefficient. Let $v=\exp (w)$ be the real wage, and denote the density of its distribution by $\hat{f}_{88}(v)=\hat{f}_{88}(w) / v$. Theil's entropy coefficient is the negative of the expectation of the logarithm of the 1988 density

$$
T=-\int_{0}^{\infty} \ln \left[\hat{f_{88}}(v)\right] \hat{f_{88}}(v) d v .^{27}
$$

The Lorenz curve is another device commonly used to measure inequality. It is the locus of points with the cumulative population share on the abscissa, $F(v)=\int_{0}^{v} f(\xi) d \xi$, and the cumulative wage share, $F_{1}(v)$, which is the first moment distribution

$$
F_{1}(v)=\int_{0}^{v} \xi f_{88}(\xi) d \xi / \int_{0}^{\infty} v f_{88}(v) d v
$$

on the ordinate. The Gini coefficient is the ratio of the area enclosed by the Lorenz curve and the diagonal line to the total area below the diagonal. It thus takes on a minimum value of zero (perfect equality) when the Lorenz curve coincides with the diagonal, and a maximum value of one (perfect inequality).

\footnotetext{
${ }^{27}$ For example, if the distribution is normal with mean $\mu$ and variance $\sigma^{2}$, it is easily shown that this measure of inequality depends only on the variance: $T=\frac{1}{2} \ln 2 \pi e \sigma^{2}$.
} 
For the estimated density of wages for 1988 , the Gini coefficient is given by

$$
G=1-2 \int_{0}^{\infty} \hat{F}_{1}(v) \hat{f}_{88}(v) d v .
$$

One drawback of these summary measures is that they provide little information on the different shapes of two distributions. Given our focus on what happens where in the distribution, it is useful to provide a measure of the divergence between the distributions that relates more directly to the density differences presented in Figures 6 and 7. We use the statistical measure of "distance" or "divergence" between two densities $f_{1}$ and $f_{2}$ considered by Kullback and Leibler (1951): ${ }^{28}$

$$
J_{12}(w)=\int_{0}^{\infty}\left[f_{1}(w)-f_{2}(w)\right] \ln \frac{f_{1}(w)}{f_{2}(w)} d w .
$$

Table III presents our decomposition results for various measures of wage dispersion and for Kullback-Leibler measure of divergence. In parentheses underneath each estimate, we present the percentage of the total change explained by each specific factor. Starting with the measures of wage dispersion for men, we note that the effect of the minimum wage is greatest on measures pertaining to the lower part of the distribution. This is consistent with the graphical results presented earlier. The minimum wage explains 25 percent of the change in the 10-90 differential, 66 percent of the change in the 10-50 differential, and 49 percent of the change in the 5-95 differential. The minimum wage thus seems to explain why changes in wage inequality during the 1980 's came mostly from longer tails at the low end of the distribution (Buchinsky (1994)). The minimum wage on the other hand, explains very little of the change in the 50-90 or the $25-75$ differential. Overall, it explains 25 percent of the change in the standard deviation of log wages.

The visually apparent contribution of unions to the declining "middle" of the distribution of men's wages translates into a 14 percent change in the standard deviation of log wages. The magnitude of this effect is comparable to the results of both Card (1996) and Freeman (1993). Changes in the distribution of individual attributes, likewise, explain about 14 percent of the change in the standard deviation. Supply and demand effects are also quite important for men. These effects explain between 20 and 30 percent of changes in the standard deviation and in the 10-90 and 25-75 wage differentials.

It is interesting to note that the various factors have quite different effects on changes in Theil's coefficient versus changes in the Gini coefficient for men. Changes in individual attributes explain the greatest proportion of the change in Theil's coefficient over the period-62 percent. On the other hand, the most important factor in explaining changes in the Gini coefficient is changes in

\footnotetext{
${ }^{28}$ The Kullback-Leibler divergence measure is written in terms of Shannon's measure of information that is used to discriminate between the two statistical populations.
} 
TABLE III

Decomposing Changes in Measures of Wage Dispersion: 1979-1988

\begin{tabular}{|c|c|c|c|c|c|c|}
\hline \multirow[b]{2}{*}{ Statistic } & \multirow[b]{2}{*}{$\begin{array}{c}\text { Total } \\
\text { Change }\end{array}$} & \multicolumn{4}{|c|}{ Effect of: } & \multirow[b]{2}{*}{$\begin{array}{c}U_{\text {Chexplained }}^{b} \\
\text { Change }\end{array}$} \\
\hline & & $\begin{array}{c}\text { Minimum } \\
\text { Wage }\end{array}$ & Unions & $\begin{array}{c}\text { Individual }^{\mathrm{a}} \\
\text { Attributes }\end{array}$ & $\begin{array}{l}\text { Supply\& } \\
\text { Demand }\end{array}$ & \\
\hline \multicolumn{7}{|l|}{ MEN: } \\
\hline $\begin{array}{l}\text { Standard } \\
\text { Deviation }^{c}\end{array}$ & 0.072 & $\begin{array}{l}0.018 \\
(24.8)\end{array}$ & $\begin{array}{c}0.010 \\
(14.3)\end{array}$ & $\begin{array}{c}0.010 \\
(14.3)\end{array}$ & $\begin{array}{l}0.016 \\
(22.3)\end{array}$ & $\begin{array}{l}0.017 \\
(24.4)\end{array}$ \\
\hline $10-90^{d}$ & 0.195 & $\begin{array}{l}0.049 \\
(25.3)\end{array}$ & $\begin{array}{c}0.021 \\
(10.7)\end{array}$ & $\begin{array}{l}0.040 \\
(20.7)\end{array}$ & $\begin{array}{l}0.040 \\
(20.7)\end{array}$ & $\begin{array}{c}0.044 \\
(22.6)\end{array}$ \\
\hline $10-50$ & 0.076 & $\begin{array}{l}0.050 \\
(65.7)\end{array}$ & $\begin{array}{r}-0.019 \\
(-25.6)\end{array}$ & $\begin{array}{l}0.038 \\
(49.7)\end{array}$ & $\begin{array}{l}0.008 \\
(10.9)\end{array}$ & $\begin{array}{l}-0.001 \\
(-0.7)\end{array}$ \\
\hline 50-90 & 0.119 & $\begin{array}{l}-0.000 \\
(-0.4)\end{array}$ & $\begin{array}{c}0.040 \\
(33.7)\end{array}$ & $\begin{array}{l}0.003 \\
(2.3)\end{array}$ & $\begin{array}{l}0.032 \\
(27.0)\end{array}$ & $\begin{array}{c}0.045 \\
(37.5)\end{array}$ \\
\hline $25-75$ & 0.109 & $\begin{array}{l}-0.001 \\
(-0.6)\end{array}$ & $\begin{array}{c}0.031 \\
(28.7)\end{array}$ & $\begin{array}{l}-0.000 \\
(-0.0)\end{array}$ & $\begin{array}{l}0.027 \\
(24.9)\end{array}$ & $\begin{array}{c}0.051 \\
(47.1)\end{array}$ \\
\hline $5-95$ & 0.290 & $\begin{array}{c}0.141 \\
(48.6)\end{array}$ & $\begin{array}{l}0.025 \\
(8.7)\end{array}$ & $\begin{array}{c}0.051 \\
(17.5)\end{array}$ & $\begin{array}{l}0.046 \\
(15.8)\end{array}$ & $\begin{array}{l}0.027 \\
(9.4)\end{array}$ \\
\hline $\begin{array}{l}\text { Theil's } \\
\text { Coefficient }\end{array}$ & 0.113 & $\begin{array}{c}0.038 \\
(34.0)\end{array}$ & $\begin{array}{l}0.003 \\
(3.0)\end{array}$ & $\begin{array}{c}0.070 \\
(61.6)\end{array}$ & $\begin{array}{l}0.026 \\
(23.4)\end{array}$ & $\begin{array}{l}-0.025 \\
(-22.2)\end{array}$ \\
\hline $\begin{array}{l}\text { Gini } \\
\text { Coefficient }\end{array}$ & 0.041 & $\begin{array}{l}0.005 \\
(11.3)\end{array}$ & $\begin{array}{c}0.009 \\
(21.1)\end{array}$ & $\begin{array}{l}0.003 \\
(7.9)\end{array}$ & $\begin{array}{l}0.011 \\
(26.6)\end{array}$ & $\begin{array}{c}0.013 \\
(33.0)\end{array}$ \\
\hline $\begin{array}{l}\text { Kullback- } \\
\text { Leibler ' } J \text { 'e }\end{array}$ & 0.092 & $\begin{array}{c}0.053 \\
(57.5)\end{array}$ & $\begin{array}{l}0.013 \\
(13.9)\end{array}$ & $\begin{array}{l}-0.005 \\
(-5.9)\end{array}$ & $\begin{array}{l}0.012 \\
(12.8)\end{array}$ & $\begin{array}{l}0.020 \\
(21.6)\end{array}$ \\
\hline \multicolumn{7}{|l|}{ WOMEN: } \\
\hline $\begin{array}{l}\text { Standard } \\
\text { Deviation }^{c}\end{array}$ & 0.090 & $\begin{array}{c}0.027 \\
(30.2)\end{array}$ & $\begin{array}{l}0.003 \\
(3.2)\end{array}$ & $\begin{array}{l}0.023 \\
(25.9)\end{array}$ & $\begin{array}{l}0.017 \\
(19.3)\end{array}$ & $\begin{array}{c}0.019 \\
(21.2)\end{array}$ \\
\hline $10-90^{d}$ & 0.328 & $\begin{array}{l}0.148 \\
(45.1)\end{array}$ & $\begin{array}{l}0.004 \\
(1.3)\end{array}$ & $\begin{array}{l}0.084 \\
(25.6)\end{array}$ & $\begin{array}{l}0.036 \\
(11.1)\end{array}$ & $\begin{array}{c}0.056 \\
(16.9)\end{array}$ \\
\hline $10-50$ & 0.243 & $\begin{array}{c}0.150 \\
(61.7)\end{array}$ & $\begin{array}{l}-0.010 \\
(-4.1)\end{array}$ & $\begin{array}{l}0.078 \\
(32.1)\end{array}$ & $\begin{array}{r}-0.011 \\
(-4.5)\end{array}$ & $\begin{array}{l}0.036 \\
(14.8)\end{array}$ \\
\hline $50-90$ & 0.085 & $\begin{array}{l}-0.002 \\
(-2.5)\end{array}$ & $\begin{array}{c}0.014 \\
(16.9)\end{array}$ & $\begin{array}{l}0.006 \\
(7.0)\end{array}$ & $\begin{array}{l}0.047 \\
(55.6)\end{array}$ & $\begin{array}{l}0.020 \\
(23.0)\end{array}$ \\
\hline $25-75$ & 0.146 & $\begin{array}{l}0.011 \\
(7.4)\end{array}$ & $\begin{array}{l}0.001 \\
(0.7)\end{array}$ & $\begin{array}{c}0.049 \\
(33.7)\end{array}$ & $\begin{array}{l}0.027 \\
(18.7)\end{array}$ & $\begin{array}{l}0.058 \\
(39.5)\end{array}$ \\
\hline $5-95$ & 0.380 & $\begin{array}{c}0.169 \\
(44.3)\end{array}$ & $\begin{array}{l}0.008 \\
(2.2)\end{array}$ & $\begin{array}{l}0.083 \\
(21.9)\end{array}$ & $\begin{array}{l}0.053 \\
(14.0)\end{array}$ & $\begin{array}{l}0.067 \\
(17.6)\end{array}$ \\
\hline $\begin{array}{l}\text { Theil's } \\
\text { Coefficient }\end{array}$ & 0.302 & $\begin{array}{l}0.078 \\
(25.9)\end{array}$ & $\begin{array}{l}-0.008 \\
(-2.8)\end{array}$ & $\begin{array}{c}0.148 \\
(48.9)\end{array}$ & $\begin{array}{l}0.021 \\
(6.8)\end{array}$ & $\begin{array}{l}0.063 \\
(21.0)\end{array}$ \\
\hline $\begin{array}{l}\text { Gini } \\
\text { Coefficient }\end{array}$ & 0.049 & $\begin{array}{l}0.011 \\
(23.3)\end{array}$ & $\begin{array}{l}0.003 \\
(5.1)\end{array}$ & $\begin{array}{l}0.012 \\
(23.7)\end{array}$ & $\begin{array}{l}0.013 \\
(25.7)\end{array}$ & $\begin{array}{c}0.011 \\
(22.2)\end{array}$ \\
\hline $\begin{array}{l}\text { Kullback- } \\
\text { Leibler ' } J \text { 'e }\end{array}$ & 0.250 & $\begin{array}{l}0.180 \\
(71.8)\end{array}$ & $\begin{array}{l}-0.005 \\
(-1.8)\end{array}$ & $\begin{array}{l}0.047 \\
(18.8)\end{array}$ & $\begin{array}{l}0.015 \\
(6.0)\end{array}$ & $\begin{array}{l}0.013 \\
(5.2)\end{array}$ \\
\hline
\end{tabular}

Note: Percent of total variation explained in parenthesis.

${ }^{\mathrm{a}}$ The individual attributes are experience, experience squared, education, SMSA, marital status, full-time or part-time, 3 occupational and 19 industry classes.

" "Unexplained" is the residual not accounted for by all other factors. See text for further explanation.

cStandard deviation of log wage distribution.

${ }^{d}$ Difference between the 90 th and the 10th percentiles of the log wage distribution. The 10-50, 50-90, 25-75, and 5-95 statistics are defined similarly.

${ }^{c}$ Kullback and Leibler's ' $J$ ' statistic is a measure of divergence between two distributions $f_{1}$ and $f_{2}$ :

$$
J=\int_{0}^{\infty}\left[f_{1}(w)-f_{2}(w)\right] \ln \left(f_{1}(w) / f_{2}(w)\right) d w .
$$

The effect of an explanatory factor indicates how much of the divergence between the 1988 and the 1979 density is explained by replacing the 1988 density by the corresponding counterfactual density. 
supply and demand which account for 27 percent of the total. These differences reflect the fact that the Gini coefficient puts relatively more weight on the middle of the distribution while Theil's coefficient emphasizes the tails.

The second half of Table III displays a similar decomposition for women. Most of the patterns are similar although, not surprisingly, changes in the unionization rate explain less of the change in wage dispersion than they do for men. By contrast, the effect of changes in the minimum wage on changes in the standard deviation of log wages is larger (30 percent) for women than for men (25 percent). In addition, changes in individual attributes generally have a more important effect than changes in supply and demand, which is not true for men. Note also that the minimum wage has a large effect on both changes in the Gini and Theil's coefficient. The effect of the minimum wage on the Gini coefficient is larger for women than for men since the minimum wage is closer to the middle of the distribution of women's wages.

In terms of the Kullback-Leibler measure of divergence, the most important explanatory factor is the minimum wage. For both men and women, changes in the minimum wage explain over a half of the divergence between the 1979 and 1988 distributions. This measure confirms the visual impression that the minimum wage is the most important factor in the change in the distribution of wages between 1979 and 1988. It captures well the fact that, for women, the density difference adjusted for the minimum wage (Figure $7 \mathrm{~b}$ ) is much closer to a flat line than the unadjusted difference (Figure 7a). This measure also confirms the visual impression that the explanatory success of our procedure is greater for women than for men. The changes in densities unexplained by the four factors we consider amount to 22 percent of the Kullback-Leibler measure for men, and to 5 percent for women.

\subsection{Changes in Wage Dispersion Between and Within Skill Groups}

In their influential survey, Levy and Murnane (1992) note that there is an emerging consensus that changes in supply and demand factors are the leading explanation for changes in wage dispersion between "skill groups" defined by observable characteristics, such as age and education. They also note, however, the absence of such a consensus on the sources of changes in wage dispersion within workers belonging to the same skill group. Unlike supply and demand considerations, the two "institutional" explanations we consider-minimum wages and unionization-have clear and measurable impacts on both the dispersion of wages between and within different groups of workers. This suggests that institutional factors might be the leading explanation for changes in wage dispersion within skill groups. ${ }^{29}$ To address this issue, we follow Juhn, Murphy, and Pierce (1993) and estimate standard wage regressions to decom-

\footnotetext{
${ }^{29}$ Card (1996) and Freeman (1993) both show that de-unionization contributed to the increase in within-group inequality over the 1980's.
} 
pose wage dispersion between and within skill groups. ${ }^{30}$ Predicted wages from these regressions are used to compute "between" measures of wage dispersion while residuals are used to compute "within" measures.

In Table IV, we report our estimates of the between- and within-standard deviation for each of the reweighted samples used in our main decomposition. ${ }^{31}$ We also report some education and experience wage differentials which are the underlying components of measures of wage dispersion between skill groups.

As expected, changes in supply and demand factors are the most important explanations for the change in the standard deviation of wages between skill groups and play a negligible role in changes in the within-group standard deviation. In addition, institutions explain a significant share (more than 30 percent) of the change in the within-group standard deviation. Overall, the various factors explain almost all the changes in the between-group standard deviation and more than half of the change in the within-group standard deviation..$^{32}$

One surprising result, however, is that changes in the minimum wage are an important explanation for changes in both the within- and the between-group standard deviation of log wages. This raises the question of why have the large number of studies that focused on changes in wage dispersion between skill groups failed to identify the important role played by the minimum wage? Part of the answer may be that many important studies, such as Katz and Murphy (1992), Murphy and Welch (1992), and Juhn, Murphy, and Pierce (1993), have relied heavily on samples of full-time men drawn from the March CPS. In such samples, less weight is put on minimum wage workers who are more likely to work part-time. ${ }^{33}$ It is also clear from Figure 1 that the minimum wage is less likely to emerge as a key factor in descriptive work that focuses on men rather than on women.

Another part of the answer may be that the importance of the minimum wage has been masked by a focus on a few standard wage differentials. For instance, many studies have looked primarily at explanations for changes in the college/high school wage premium. As Table IV indicates, the minimum wage played no role in the 0.141 increase in the college/high school premium for men

\footnotetext{
${ }^{30}$ The variables included in our log wage regressions consist of 32 gender-experience-education dummies (corresponding to the groups defined in Section 3.4) fully interacted with experience, experience squared, years of education, a marital status dummy, and a race dummy.

${ }^{31}$ One advantage of decomposing the variance (or the standard deviation) into a between and a within component is that these two components aggregate up to the total variance. Measures like the 10-90 differential do not aggregate up. The results of the between/within decomposition are not very sensitive, however, to the choice of inequality indices. We find that the within component accounts for 43 percent of the increase in the variance of wages. Juhn, Murphy, and Pierce (1993) obtain the same percentage for the same time period using the 10-90 differential.

${ }^{32}$ Changes in the distribution of attributes include changes in the industrial and occupational distribution of the workforce. This explains why changes in the distribution of attributes accounts for a third of the change in the within-group standard deviation.

${ }^{33}$ The estimated effect of the minimum wage on the standard deviation of men's wages falls from 0.018 to 0.013 when we exclude part-time workers.
} 
TABLE IV

Changes in WAGe Dispersion Between AND Within Skill Groups: 1979-1988

\begin{tabular}{|c|c|c|c|c|c|c|}
\hline \multirow[b]{2}{*}{ Statistic } & \multirow[b]{2}{*}{$\begin{array}{c}\text { Total } \\
\text { Change }\end{array}$} & \multicolumn{4}{|c|}{ Effect of: } & \multirow[b]{2}{*}{$\begin{array}{l}\text { Unexplained }^{\mathrm{b}} \\
\text { Change }\end{array}$} \\
\hline & & $\begin{array}{c}\text { Minimum } \\
\text { Wage }\end{array}$ & Unions & $\begin{array}{l}\text { Individual }^{\mathrm{a}} \\
\text { Attributes }^{-}\end{array}$ & $\begin{array}{l}\text { Supply\& } \\
\text { Demand }\end{array}$ & \\
\hline \multicolumn{7}{|l|}{ MEN: } \\
\hline \multicolumn{7}{|l|}{ Standard Deviation } \\
\hline Within Groups & 0.038 & $\begin{array}{l}0.009 \\
(24.2)\end{array}$ & $\begin{array}{l}0.002 \\
(6.4)\end{array}$ & $\begin{array}{l}0.013 \\
(34.9)\end{array}$ & $\begin{array}{l}-0.002 \\
(-6.0)\end{array}$ & $\begin{array}{l}0.016 \\
(40.6)\end{array}$ \\
\hline Between Groups & 0.068 & $\begin{array}{l}0.017 \\
(24.7)\end{array}$ & $\begin{array}{l}0.014 \\
(20.1)\end{array}$ & $\begin{array}{l}-0.001 \\
(-1.0)\end{array}$ & $\begin{array}{c}0.030 \\
(44.0)\end{array}$ & $\begin{array}{l}0.008 \\
(12.6)\end{array}$ \\
\hline \multicolumn{7}{|l|}{$\begin{array}{l}\text { Education Differentials } \\
(0-9 \text { years of exp.) }\end{array}$} \\
\hline High School-Dropout & -0.003 & 0.058 & -0.031 & 0.008 & 0.009 & -0.047 \\
\hline College-High School & 0.228 & 0.031 & 0.043 & -0.005 & 0.094 & 0.065 \\
\hline \multicolumn{7}{|l|}{$\begin{array}{l}\text { Education Differentials } \\
(20-29 \text { yrs. of exp.) }\end{array}$} \\
\hline High School-Dropout & 0.092 & 0.015 & 0.051 & 0.011 & 0.020 & -0.005 \\
\hline College-High School & 0.141 & -0.007 & 0.025 & 0.002 & 0.108 & 0.013 \\
\hline \multicolumn{7}{|l|}{ Experience Differentials ${ }^{c}$} \\
\hline Dropouts & 0.014 & 0.079 & -0.062 & -0.020 & 0.024 & -0.007 \\
\hline High School & 0.109 & 0.037 & 0.020 & -0.017 & 0.035 & 0.034 \\
\hline College & 0.123 & 0.016 & 0.027 & -0.001 & 0.025 & 0.057 \\
\hline \multicolumn{7}{|l|}{ WOMEN: } \\
\hline \multicolumn{7}{|l|}{ Standard Deviation } \\
\hline Within Groups & 0.058 & $\begin{array}{l}0.020 \\
(34.0)\end{array}$ & $\begin{array}{l}0.002 \\
(2.7)\end{array}$ & $\begin{array}{l}0.019 \\
(32.8)\end{array}$ & $\begin{array}{l}-0.004 \\
(-6.6)\end{array}$ & $\begin{array}{l}0.022 \\
(37.2)\end{array}$ \\
\hline Between Groups & 0.076 & $\begin{array}{l}0.019 \\
(25.3)\end{array}$ & $\begin{array}{l}0.003 \\
(3.8)\end{array}$ & $\begin{array}{l}0.014 \\
(17.7)\end{array}$ & $\begin{array}{l}0.043 \\
(55.7)\end{array}$ & $\begin{array}{l}-0.002 \\
(-2.4)\end{array}$ \\
\hline \multicolumn{7}{|l|}{$\begin{array}{l}\text { Education Differentials } \\
(0-9 \text { yrs. of exp. })\end{array}$} \\
\hline High School-Dropout & 0.046 & 0.043 & -0.008 & 0.015 & -0.010 & 0.007 \\
\hline College-High School & 0.192 & 0.043 & 0.008 & 0.013 & 0.129 & -0.001 \\
\hline \multicolumn{7}{|l|}{$\begin{array}{l}\text { Education Differentials } \\
(20-29 \text { yrs. of exp.) }\end{array}$} \\
\hline High School-Dropout & 0.136 & 0.034 & 0.011 & 0.021 & 0.002 & 0.068 \\
\hline College-High School & 0.082 & 0.021 & 0.000 & 0.005 & 0.209 & -0.154 \\
\hline \multicolumn{7}{|l|}{ Experience Differentials $^{c}$} \\
\hline Dropouts & 0.022 & 0.040 & -0.020 & -0.012 & 0.014 & -0.001 \\
\hline High School & 0.111 & 0.032 & 0.000 & -0.006 & 0.026 & 0.059 \\
\hline College & 0.167 & 0.013 & 0.010 & 0.008 & 0.042 & 0.095 \\
\hline
\end{tabular}

Note: Percent of total variation explained in parenthesis.

${ }^{\mathrm{a}}$ The individual attributes are experience squared, education, SMSA, marital status, full-time or part-time, 3 occupational and 19 industry classes.

b، Unexplained" is the residual not accounted for by all other factors. See text for further explanation.

${ }^{c}$ Difference between the mean log wage of workers with 20 to 29 years of experience and the mean log wage of workers with 0 to 9 years of experience. 
with 20 to 29 years of experience. Even for young men with 0 to 9 years of experience, the minimum wage only explains 10 percent of the striking 0.228 increase in the college/high school premium. These results are comparable to those of Blackburn, Bloom, and Freeman (1992) who find that the effect of the minimum wage on changes in the college/high school differentials ranges from 0.00 to 0.01 .

On the other hand, Blackburn, Bloom, and Freeman (1992) report much larger effects of the minimum wage (0.04) on changes in the high school/dropout wage differential for black females. The magnitude of this effect compares to our estimated effect of the minimum wage on changes in high school/dropout differentials for young men (0.06) and women (0.04). This suggests that the minimum wage has a sizable effect on differentials involving the lowest paid groups of workers (black female or youth who have not completed high school). This helps explain why, for men, the minimum wage has an important effect on changes in measures that put more weight on the tails than on the middle of the distribution, like the variance of log wages or Theil's coefficient.

Lastly, one important difference between this and previous work is a matter of emphasis. For example, Blackburn, Bloom, and Freeman (1992) have already noted that the minimum wage has a sizable effect on changes in wages of low-paid workers. ${ }^{34}$ Our "visual" approach directly highlights this fact. Although previous research has found some distributional effects of the minimum wage, our graphical analysis shows more clearly that minimum wages cannot be ignored in any study of the determinants of changes in wage inequality over the 1980 's - especially for women.

\section{SUPPORTING EVIDENCE}

\subsection{Reversing the Order of the Decomposition}

In Table V, we repeat the analysis of Table III in reverse order. We thus perform our sequential analysis beginning with the effect of changes in supply and demand, followed by the effect of individual attributes other than unionization, then by unionization, and with minimum wage effects last. Reversing the order of the decomposition unambiguously increases the effect of supply and demand factors and diminishes the role of changes in the minimum wage. The rationale behind this result is that fewer "low-skilled" workers would have been at risk of being affected by the minimum wage in 1988 if the demand for their services had not deteriorated the way it did over the 1980's. Holding supply and

\footnotetext{
${ }^{34}$ Horrigan and Mincy (1993) also find that the minimum wage has a larger impact on workers in the lower tail of the distribution than on other workers. Their conclusion that raising the minimum wage would have only a small effect on the 1987 distribution of wages is not necessarily incompatible, however, with minimum wages having a sizable effect on changes in the distribution of wages. The latter is a question of what percentage of the total change in the distribution is explained by changes in the minimum wage.
} 
TABLE V

REVERSING THE ORDER OF THE DECOMPOSITION: 1979-1988

\begin{tabular}{|c|c|c|c|c|c|c|}
\hline \multirow[b]{2}{*}{ Statistic } & \multirow[b]{2}{*}{$\begin{array}{c}\text { Total } \\
\text { Change }\end{array}$} & \multicolumn{4}{|c|}{ Effect of: } & \multirow[b]{2}{*}{$\begin{array}{c}\text { Unexplained }^{b} \\
\text { Change }\end{array}$} \\
\hline & & $\begin{array}{l}\text { Supply\& } \\
\text { Demand }\end{array}$ & $\begin{array}{l}\text { Individual }^{\mathrm{a}} \\
\text { Attributes }^{2}\end{array}$ & Unions & $\begin{array}{c}\text { Minimum } \\
\text { Wage }\end{array}$ & \\
\hline \multicolumn{7}{|l|}{ MEN: } \\
\hline $\begin{array}{l}\text { Standard } \\
\text { Deviation }^{c}\end{array}$ & 0.072 & $\begin{array}{l}0.023 \\
(32.1)\end{array}$ & $\begin{array}{c}0.004 \\
(5.7)\end{array}$ & $\begin{array}{l}0.015 \\
(21.0)\end{array}$ & $\begin{array}{c}0.012 \\
(16.9)\end{array}$ & $\begin{array}{c}0.017 \\
(24.4)\end{array}$ \\
\hline $10-90^{\mathrm{d}}$ & 0.195 & $\begin{array}{l}0.063 \\
(32.4)\end{array}$ & $\begin{array}{l}0.009 \\
(4.8)\end{array}$ & $\begin{array}{l}0.047 \\
(24.1)\end{array}$ & $\begin{array}{c}0.031 \\
(16.0)\end{array}$ & $\begin{array}{l}0.044 \\
(22.6)\end{array}$ \\
\hline $10-50$ & 0.076 & $\begin{array}{l}0.026 \\
(33.9)\end{array}$ & $\begin{array}{c}0.020 \\
(26.9)\end{array}$ & $\begin{array}{l}-0.004 \\
(-5.5)\end{array}$ & $\begin{array}{c}0.034 \\
(45.3)\end{array}$ & $\begin{array}{l}-0.001 \\
(-0.7)\end{array}$ \\
\hline $50-90$ & 0.119 & $\begin{array}{l}0.038 \\
(31.5)\end{array}$ & $\begin{array}{l}-0.011 \\
(-9.2)\end{array}$ & $\begin{array}{c}0.051 \\
(42.8)\end{array}$ & $\begin{array}{l}-0.003 \\
(-2.6)\end{array}$ & $\begin{array}{l}0.045 \\
(37.5)\end{array}$ \\
\hline $25-75$ & 0.109 & $\begin{array}{l}0.030 \\
(27.8)\end{array}$ & $\begin{array}{l}-0.000 \\
(-0.4)\end{array}$ & $\begin{array}{l}0.032 \\
(29.8)\end{array}$ & $\begin{array}{l}-0.005 \\
(-4.2)\end{array}$ & $\begin{array}{l}0.051 \\
(47.1)\end{array}$ \\
\hline 5-95 & 0.290 & $\begin{array}{l}0.088 \\
(30.3)\end{array}$ & $\begin{array}{l}0.018 \\
(6.1)\end{array}$ & $\begin{array}{c}0.041 \\
(14.3)\end{array}$ & $\begin{array}{c}0.116 \\
(40.0)\end{array}$ & $\begin{array}{l}0.027 \\
(9.4)\end{array}$ \\
\hline $\begin{array}{l}\text { Theil's } \\
\text { Coefficient }\end{array}$ & 0.113 & $\begin{array}{l}0.044 \\
(39.4)\end{array}$ & $\begin{array}{c}0.057 \\
(50.2)\end{array}$ & $\begin{array}{l}0.002 \\
(2.0)\end{array}$ & $\begin{array}{c}0.034 \\
(30.6)\end{array}$ & $\begin{array}{l}-0.025 \\
(-22.2)\end{array}$ \\
\hline $\begin{array}{l}\text { Gini } \\
\text { Coefficient }\end{array}$ & 0.041 & $\begin{array}{l}0.013 \\
(32.5)\end{array}$ & $\begin{array}{l}-0.000 \\
(-1.0)\end{array}$ & $\begin{array}{c}0.011 \\
(28.3)\end{array}$ & $\begin{array}{l}0.003 \\
(7.3)\end{array}$ & $\begin{array}{c}0.013 \\
(33.0)\end{array}$ \\
\hline $\begin{array}{l}\text { Kullback- } \\
\text { Leibler ' } J \text { ' }\end{array}$ & 0.092 & $\begin{array}{l}0.027 \\
(29.7)\end{array}$ & $\begin{array}{r}-0.025 \\
(-27.1)\end{array}$ & $\begin{array}{l}0.027 \\
(29.4)\end{array}$ & $\begin{array}{l}0.043 \\
(46.6)\end{array}$ & $\begin{array}{l}0.020 \\
(21.6)\end{array}$ \\
\hline \multicolumn{7}{|l|}{ WOMEN: } \\
\hline $\begin{array}{l}\text { Standard } \\
\text { Deviation }^{\mathrm{c}}\end{array}$ & 0.090 & $\begin{array}{l}0.030 \\
(33.4)\end{array}$ & $\begin{array}{l}0.019 \\
(20.7)\end{array}$ & $\begin{array}{l}0.001 \\
(0.6)\end{array}$ & $\begin{array}{l}0.022 \\
(24.1)\end{array}$ & $\begin{array}{l}0.019 \\
(21.2)\end{array}$ \\
\hline $10-90^{d}$ & 0.328 & $\begin{array}{l}0.088 \\
(26.8)\end{array}$ & $\begin{array}{l}0.048 \\
(14.6)\end{array}$ & $\begin{array}{l}-0.000 \\
(-0.0)\end{array}$ & $\begin{array}{l}0.137 \\
(41.6)\end{array}$ & $\begin{array}{l}0.056 \\
(16.9)\end{array}$ \\
\hline $10-50$ & 0.243 & $\begin{array}{l}0.032 \\
(13.0)\end{array}$ & $\begin{array}{l}0.045 \\
(18.7)\end{array}$ & $\begin{array}{l}-0.007 \\
(-3.0)\end{array}$ & $\begin{array}{c}0.138 \\
(56.5)\end{array}$ & $\begin{array}{l}0.036 \\
(14.8)\end{array}$ \\
\hline 50-90 & 0.085 & $\begin{array}{l}0.057 \\
(66.5)\end{array}$ & $\begin{array}{l}0.003 \\
(3.0)\end{array}$ & $\begin{array}{l}0.007 \\
(8.6)\end{array}$ & $\begin{array}{l}-0.001 \\
(-1.1)\end{array}$ & $\begin{array}{l}0.020 \\
(23.0)\end{array}$ \\
\hline $25-75$ & 0.146 & $\begin{array}{l}0.045 \\
(30.6)\end{array}$ & $\begin{array}{l}0.031 \\
(21.0)\end{array}$ & $\begin{array}{l}-0.002 \\
(-1.2)\end{array}$ & $\begin{array}{l}0.015 \\
(10.2)\end{array}$ & $\begin{array}{c}0.058 \\
(39.5)\end{array}$ \\
\hline 5-95 & 0.380 & $\begin{array}{l}0.105 \\
(27.6)\end{array}$ & $\begin{array}{l}0.073 \\
(19.3)\end{array}$ & $\begin{array}{l}-0.002 \\
(-0.4)\end{array}$ & $\begin{array}{l}0.137 \\
(35.9)\end{array}$ & $\begin{array}{l}0.067 \\
(17.6)\end{array}$ \\
\hline $\begin{array}{l}\text { Theil's } \\
\text { Coefficient }\end{array}$ & 0.302 & $\begin{array}{l}0.062 \\
(20.5)\end{array}$ & $\begin{array}{c}0.115 \\
(38.0)\end{array}$ & $\begin{array}{l}-0.014 \\
(-4.8)\end{array}$ & $\begin{array}{c}0.076 \\
(25.3)\end{array}$ & $\begin{array}{l}0.063 \\
(21.0)\end{array}$ \\
\hline Gini & 0.049 & 0.018 & 0.008 & 0.001 & 0.011 & 0.011 \\
\hline Coefficient & & (37.7) & (15.9) & $(2.2)$ & $(22.0)$ & $(22.2)$ \\
\hline $\begin{array}{l}\text { Kullback- } \\
\text { Leibler ' } J \text { ' }\end{array}$ & 0.250 & $\begin{array}{l}0.053 \\
(21.2)\end{array}$ & $\begin{array}{l}0.002 \\
(0.6)\end{array}$ & $\begin{array}{l}0.007 \\
(2.6)\end{array}$ & $\begin{array}{l}0.176 \\
(70.3)\end{array}$ & $\begin{array}{l}0.013 \\
(5.2)\end{array}$ \\
\hline
\end{tabular}

Note: Percent of total variation explained in parenthesis.

${ }^{a}$ The individual attributes are experience, experience squared, education, SMSA, marital status, full-time or part-time, 3 occupational and 19 industry classes.

"'Unexplained" is the residual not accounted for by all other factors. See text for further explanation.

'Standard deviation of log wage distribution.

dDifference between the 90th and the 10th percentiles of the log wage distribution. The 10-50, 50-90, 25-75, and 5-95 statistics are defined similarly.

${ }^{c}$ Kullback and Leibler's ' $J$ ' statistic is a measure of divergence between two distributions $f_{1}$ and $f_{2}$ :

$$
J=\int_{0}^{\infty}\left[f_{1}(w)-f_{2}(w)\right] \ln \left(f_{1}(w) / f_{2}(w)\right) d w .
$$

The effect of an explanatory factor indicates how much of the divergence between the 1988 and the 1979 density is explained by replacing the 1988 density by the corresponding counterfactual density. 
demand conditions at their 1979 level thus reduces the potential impact of changes in the minimum wage.

Note that for men, however, the impact of changes in unionization on the standard deviation of log wages increases from 14.3 percent to 21 percent of the total change when we reverse the order of the decomposition. The total effect of labor market institutions, approximately 38 percent of the total change in the standard deviation, is thus relatively robust to changes in the order of the decomposition. While the precise percentages explained by the various factors are not identical when we reverse the order of the decomposition, the qualitative results are not affected.

\subsection{Changes in the Distribution of Wages: $1973-1979$ and 1988-1992}

Over the 1973-79 period, both the real value of the minimum wage and coverage rose substantially. The unionization rate increased slightly for both men and women because of the growth in public sector unionization. If our results for 1979-88 are not spurious consequences of the particular period analyzed, the effect of labor market institutions on changes in wage inequality for 1973-79 should be the reverse of that which we obtain for 1979-88. Increases in minimum wages and unionization rates should therefore reduce wage inequality over the 1973-79 period.

In Table VI, we decompose the changes in the standard deviation of log wages for the period 1973-1979, as well as for 1988-92. For men, minimum wage changes explain 35 percent of the decline in the standard deviation of log wages for the 1973 to 1979 period, while unions explain 26 percent. $^{35}$ For women, changes in the minimum wage explain 29 percent of the decline in the standard deviation of log wages, while changes in the unionization rate have virtually no effect. These results support our prediction that labor market institutions should have opposite effects over the 1973-79 and the 1979-88 periods.

We also decompose the standard deviation of log wages into a between- and a within-group component in Table VI. One important feature of our May/outgoing rotation group CPS data is that the within-group standard deviation of log wages decreased between 1973 and 1979. This is at odds with analyses based on March CPS data which concluded that wage dispersion within skill groups increased during the 1970's (Juhn, Murphy, and Pierce (1993)). It is consistent, however, with results reported by Card and Lemieux (1996) using data similar to

\footnotetext{
${ }^{35}$ The effect of changes in the level of unionization on changes in wage inequality is entirely due to the growth of public sector unionization over this period, which went from 23 percent to 38 percent. Private sector unionization declined from 24 percent to 22 percent over this period and would have caused a slight increase of 0.0003 in the standard deviation of log wages for men.
} 
TABLE VI

Changes in Measures of Wage Dispersion: 1973-79 AND 1988-92

\begin{tabular}{|c|c|c|c|c|c|c|}
\hline \multirow[b]{3}{*}{ Statistic } & \multicolumn{3}{|c|}{ 1973-79: } & \multicolumn{3}{|c|}{ 1988-92: } \\
\hline & \multirow[b]{2}{*}{$\begin{array}{c}\text { Total } \\
\text { Change }\end{array}$} & \multicolumn{2}{|c|}{ Effect of: } & \multirow[b]{2}{*}{$\begin{array}{c}\text { Total } \\
\text { Change }\end{array}$} & \multicolumn{2}{|c|}{ Effect of: } \\
\hline & & $\begin{array}{c}\text { Minimum } \\
\text { Wage }\end{array}$ & Unions & & $\begin{array}{c}\text { Minimum } \\
\text { Wage }\end{array}$ & Unions \\
\hline \multicolumn{7}{|l|}{ MEN: } \\
\hline \multicolumn{7}{|l|}{ Standard Deviation } \\
\hline Total & -0.013 & $\begin{array}{c}-0.004 \\
(34.6)\end{array}$ & $\begin{array}{l}-0.003 \\
(26.2)\end{array}$ & 0.004 & $\begin{array}{l}0.000 \\
(4.0)\end{array}$ & $\begin{array}{l}0.003 \\
(70.2)\end{array}$ \\
\hline Within Groups & -0.012 & $\begin{array}{l}-0.002 \\
(18.2)\end{array}$ & $\begin{array}{l}-0.003 \\
(24.6)\end{array}$ & 0.007 & $\begin{array}{c}0.001 \\
(10.1)\end{array}$ & $\begin{array}{c}0.001 \\
(16.1)\end{array}$ \\
\hline Between Groups & -0.000 & $\begin{array}{c}-0.002 \\
(-)\end{array}$ & $\begin{array}{c}-0.000 \\
(-)\end{array}$ & -0.002 & $\begin{array}{l}-0.001 \\
(26.5)\end{array}$ & $\begin{array}{r}0.003 \\
(-125.9)\end{array}$ \\
\hline \multicolumn{7}{|l|}{$\begin{array}{l}\text { Education Differentials } \\
(0-9 \text { yrs. of exp. })\end{array}$} \\
\hline High School-Dropout & -0.027 & $\begin{array}{l}-0.008 \\
(29.3)\end{array}$ & $\begin{array}{c}-0.002 \\
(7.6)\end{array}$ & -0.017 & $\begin{array}{l}-0.000 \\
(2.8)\end{array}$ & $\begin{array}{l}-0.004 \\
(21.9)\end{array}$ \\
\hline College-High School & -0.022 & $\begin{array}{r}0.003 \\
(-16.0)\end{array}$ & $\begin{array}{r}0.003 \\
(-15.1)\end{array}$ & 0.022 & $\begin{array}{l}-0.005 \\
(-21.4)\end{array}$ & $\begin{array}{l}0.007 \\
(31.2)\end{array}$ \\
\hline \multicolumn{7}{|l|}{$\begin{array}{l}\text { Education Differentials } \\
(20-29 \text { yrs. of exp.) }\end{array}$} \\
\hline High School-Dropout & 0.017 & $\begin{array}{l}-0.006 \\
(-36.3)\end{array}$ & $\begin{array}{l}0.013 \\
(76.1)\end{array}$ & 0.002 & $\begin{array}{l}-0.000 \\
(-19.9)\end{array}$ & $\begin{array}{r}0.006 \\
(298.4)\end{array}$ \\
\hline College-High School & -0.063 & $\begin{array}{c}0.004 \\
(-5.7)\end{array}$ & $\begin{array}{l}-0.023 \\
(37.0)\end{array}$ & 0.053 & $\begin{array}{l}-0.002 \\
(-3.2)\end{array}$ & $\begin{array}{c}0.012 \\
(22.7)\end{array}$ \\
\hline \multicolumn{7}{|l|}{ WOMEN: } \\
\hline \multicolumn{7}{|l|}{ Standard Deviation } \\
\hline Total & -0.032 & $\begin{array}{l}-0.009 \\
(28.6)\end{array}$ & $\begin{array}{r}0.001 \\
(-1.9)\end{array}$ & 0.011 & $\begin{array}{l}0.002 \\
(20.7)\end{array}$ & $\begin{array}{l}0.001 \\
(8.4)\end{array}$ \\
\hline Within Groups & -0.022 & $\begin{array}{l}-0.007 \\
(31.7)\end{array}$ & $\begin{array}{l}-0.004 \\
(16.7)\end{array}$ & 0.007 & $\begin{array}{c}0.002 \\
(23.2)\end{array}$ & $\begin{array}{l}0.001 \\
(8.4)\end{array}$ \\
\hline Between Groups & -0.026 & $\begin{array}{l}-0.006 \\
(24.2)\end{array}$ & $\begin{array}{r}0.007 \\
(-29.0)\end{array}$ & 0.009 & $\begin{array}{l}0.002 \\
(18.3)\end{array}$ & $\begin{array}{l}0.001 \\
(8.6)\end{array}$ \\
\hline \multicolumn{7}{|l|}{$\begin{array}{l}\text { Education Differentials } \\
(0-9 \text { yrs. of exp.) }\end{array}$} \\
\hline High School-Dropout & -0.034 & $\begin{array}{l}-0.007 \\
(21.5)\end{array}$ & $\begin{array}{r}0.001 \\
(-2.5)\end{array}$ & -0.031 & $\begin{array}{r}0.000 \\
(-1.1)\end{array}$ & $\begin{array}{c}-0.001 \\
(6.3)\end{array}$ \\
\hline College-High School & -0.071 & $\begin{array}{l}-0.005 \\
(7.7)\end{array}$ & $\begin{array}{r}0.004 \\
(-5.1)\end{array}$ & 0.017 & $\begin{array}{l}0.001 \\
(5.8)\end{array}$ & $\begin{array}{l}0.002 \\
(9.7)\end{array}$ \\
\hline \multicolumn{7}{|l|}{$\begin{array}{l}\text { Education Differentials } \\
(20-29 \text { yrs. of exp.) }\end{array}$} \\
\hline High School-Dropout & -0.069 & $\begin{array}{l}-0.013 \\
(18.5)\end{array}$ & $\begin{array}{c}0.006 \\
(-8.3)\end{array}$ & 0.005 & $\begin{array}{c}0.003 \\
(63.1)\end{array}$ & $\begin{array}{c}-0.001 \\
(-10.2)\end{array}$ \\
\hline College-High School & -0.135 & $\begin{array}{c}-0.004 \\
(2.8)\end{array}$ & $\begin{array}{r}0.032 \\
(-23.9)\end{array}$ & 0.075 & $\begin{array}{l}0.000 \\
(0.6)\end{array}$ & $\begin{array}{c}0.001 \\
(1.7)\end{array}$ \\
\hline
\end{tabular}


ours. ${ }^{36}$ Table VI also shows that, as in $1979-88$, the minimum wage was important in explaining changes in both the within- and the between-group standard deviation of wages over the 1973-79 period.

The period 1988-1992 is less interesting for the analysis of institutional factors since there was virtually no change in the unionization rate over this period for men or women, and minimum wages rose only by 11 percent from 1988 to $1992 .{ }^{37}$ We nevertheless present the 1988-1992 results for completeness. We show in Table VI that, for men, there was virtually no change in the standard deviation of log wages. For women, the results show a slight increase in wage inequality as measured by the standard deviation of $\log$ wages with neither unions nor minimum wages explaining much of the effect.

\section{CONCLUSIONS}

In this paper, we have proposed and implemented a semiparametric procedure to analyze the effect of various factors on changes in the distribution of wages. This procedure yields a visually clear representation of precisely where in the distribution various factors have their greatest impact. It could be fruitfully applied to many other problems where it is useful to know what part of the distribution is affected. For example, the procedure could be used to illustrate the impact of social programs, such as welfare and unemployment insurance, on the distribution of family income.

As has been documented in previous research, we also find that de-unionization and supply and demand shocks are important factors explaining the rise in wage inequality from 1979 to 1988 . In addition, however, we find that the decline in the real value of the minimum wage from 1979 to 1988 explains a substantial proportion of the increase in wage inequality, particularly for women and for others in the lower tail of the wage distribution. We conclude that labor market institutions are as important as supply and demand considerations in explaining changes in the U.S. distribution of wages from 1979 to 1988.

We also find that the increase in unionization and in the real value of the minimum wage between 1973 and 1979 contributed to the decrease in wage inequality over that period. In an earlier version of this paper (DiNardo, Fortin, and Lemieux (1994)), we showed that changes in the value of the minimum wage had a larger impact on changes in wage inequality in "low wage" states than in "high wage" states. We also showed that the relative constancy of the unioniza-

\footnotetext{
${ }^{36}$ Card and Lemieux (1996) report that the within-group wage dispersion measured by either the standard deviation of $\log$ wages or by the 10-90 differential decreased between 1973 and 1979 . Note also that, because of changes in the composition of the workforce, the between-group standard deviation remained constant for men despite the fact that most education wage differentials decreased between 1973 and 1979. However, a "fixed weight" measure of the between-groups standard deviation would show a substantial decline over this period.

${ }^{37}$ By 1988, many states had legislated minimum wage increases above the federal minimum. When appropriate, we thus use these state minimum wages to compute the effect of changes in the minimum wage on changes in the distribution of wages between 1988 and 1992.
} 
tion rate in Canada over the 1980's was an important reason for the slower growth of inequality in Canada as compared to the United States. This provides additional evidence of the importance of labor market institutions in recent changes in the distribution of wages.

Our findings about the importance of labor market institutions are in concordance with analyses that were common before the advent of the widespread use of "marginal productivity analysis" as it was called, and the growing focus on "economic" factors, such as supply and demand, in empirical labor economics. For example, in Lester's (1964) analysis of the wage structure, supply and demand played an important but secondary role to such factors as the extent of unionization and the minimum wage. Our findings suggest that this earlier emphasis was not misplaced.

Dept. of Economics, University of California-Irvine, Irvine, CA 92717, U.S.A.

Dept. of Economics, Université de Montréal, P.O. Box 6128, Station Centre-ville, Montréal, Québec, H3C 3J7, Canada

and

Dept. of Economics, Université de Montréal, P.O. Box 6128, Station Centre-ville, Montréal, Québec, H3C 3J7, Canada 
TABLE A1

MEASURES OF WAGE INEQUALITY

\begin{tabular}{|c|c|c|c|c|c|c|c|c|}
\hline Year & $\begin{array}{c}\text { Standard } \\
\text { Deviation } \\
\text { of Log Wage }\end{array}$ & $10-90$ & $\begin{array}{c}\text { of } \log \\
10-50\end{array}$ & $\begin{array}{c}\text { Percentile } \\
\text { Nage Dist } \\
50-90\end{array}$ & ution: & $5-95$ & $\begin{array}{l}\text { Theil's } \\
\text { Entropy } \\
\text { Coefficient }\end{array}$ & $\begin{array}{c}\text { Gini } \\
\text { Coefficien }\end{array}$ \\
\hline \multicolumn{9}{|c|}{ MEN } \\
\hline 1973 & 0.516 & 1.269 & 0.674 & 0.595 & 0.625 & 1.630 & 2.575 & 0.274 \\
\hline 1974 & 0.514 & 1.253 & 0.667 & 0.586 & 0.627 & 1.604 & 2.471 & 0.274 \\
\hline 1975 & 0.520 & 1.293 & 0.697 & 0.596 & 0.654 & 1.643 & 2.575 & 0.279 \\
\hline 1976 & 0.517 & 1.292 & 0.685 & 0.606 & 0.662 & 1.616 & 2.566 & 0.277 \\
\hline 1977 & 0.519 & 1.289 & 0.704 & 0.585 & 0.676 & 1.626 & 2.572 & 0.275 \\
\hline 1978 & 0.509 & 1.290 & 0.700 & 0.590 & 0.685 & 1.594 & 2.561 & 0.275 \\
\hline 1979 & 0.501 & 1.277 & 0.692 & 0.585 & 0.682 & 1.572 & 2.546 & 0.270 \\
\hline 1980 & 0.508 & 1.284 & 0.702 & 0.583 & 0.695 & 1.598 & 2.555 & 0.276 \\
\hline 1981 & 0.519 & 1.313 & 0.715 & 0.598 & 0.717 & 1.621 & 2.566 & 0.282 \\
\hline 1982 & 0.537 & 1.365 & 0.742 & 0.623 & 0.746 & 1.693 & 2.604 & 0.290 \\
\hline 1983 & 0.554 & 1.414 & 0.762 & 0.652 & 0.770 & 1.755 & 2.628 & 0.301 \\
\hline 1984 & 0.461 & 1.435 & 0.770 & 0.665 & 0.769 & 1.792 & 2.646 & 0.305 \\
\hline 1985 & 0.568 & 1.451 & 0.780 & 0.671 & 0.777 & 1.817 & 2.661 & 0.308 \\
\hline 1986 & 0.570 & 1.463 & 0.790 & 0.673 & 0.784 & 1.829 & 2.665 & 0.306 \\
\hline 1987 & 0.572 & 1.465 & 0.777 & 0.687 & 0.785 & 1.843 & 2.658 & 0.307 \\
\hline 1988 & 0.576 & 1.471 & 0.767 & 0.704 & 0.791 & 1.862 & 2.659 & 0.311 \\
\hline 1989 & 0.575 & 1.462 & 0.762 & 0.700 & 0.791 & 1.848 & 2.650 & 0.309 \\
\hline 1990 & 0.579 & 1.472 & 0.756 & 0.717 & 0.791 & 1.849 & 2.653 & 0.315 \\
\hline 1991 & 0.576 & 1.478 & 0.755 & 0.723 & 0.795 & 1.836 & 2.637 & 0.316 \\
\hline 1992 & 0.577 & 1.491 & 0.762 & 0.729 & 0.809 & 1.841 & 2.654 & 0.316 \\
\hline \multicolumn{9}{|c|}{ WOMEN } \\
\hline 1973 & 0.460 & 1.062 & 0.492 & 0.569 & 0.592 & 1.369 & 2.049 & 0.250 \\
\hline 1974 & 0.449 & 1.009 & 0.446 & 0.564 & 0.578 & 1.340 & 1.992 & 0.243 \\
\hline 1975 & 0.452 & 1.044 & 0.467 & 0.577 & 0.594 & 1.328 & 2.025 & 0.249 \\
\hline 1976 & 0.450 & 1.021 & 0.434 & 0.587 & 0.586 & 1.310 & 2.017 & 0.246 \\
\hline 1977 & 0.446 & 1.039 & 0.446 & 0.593 & 0.591 & 1.305 & 1.949 & 0.248 \\
\hline 1978 & 0.437 & 0.991 & 0.402 & 0.589 & 0.576 & 1.264 & 1.980 & 0.241 \\
\hline 1979 & 0.429 & 0.894 & 0.394 & 0.590 & 0.573 & 1.241 & 1.062 & 0.238 \\
\hline 1980 & 0.422 & 1.007 & 0.417 & 0.590 & 0.582 & 1.245 & 1.969 & 0.239 \\
\hline 1981 & 0.432 & 1.045 & 0.431 & 0.614 & 0.601 & 1.281 & 2.004 & 0.245 \\
\hline 1982 & 0.450 & 1.104 & 0.482 & 0.623 & 0.638 & 1.345 & 2.080 & 0.255 \\
\hline 1983 & 0.467 & 1.154 & 0.521 & 0.633 & 0.659 & 1.396 & 2.123 & 0.264 \\
\hline 1984 & 0.482 & 1.202 & 0.557 & 0.645 & 0.678 & 1.456 & 2.163 & 0.272 \\
\hline 1985 & 0.494 & 1.242 & 0.588 & 0.654 & 0.696 & 1.499 & 2.201 & 0.278 \\
\hline 1986 & 0.502 & 1.268 & 0.613 & 0.655 & 0.706 & 1.538 & 2.225 & 0.279 \\
\hline 1987 & 0.511 & 1.295 & 0.629 & 0.665 & 0.713 & 1.583 & 2.249 & 0.284 \\
\hline 1988 & 0.516 & 1.312 & 0.637 & 0.675 & 0.718 & 1.621 & 2.264 & 0.287 \\
\hline 1989 & 0.523 & 1.324 & 0.638 & 0.685 & 0.728 & 1.649 & 2.281 & 0.289 \\
\hline 1990 & 0.524 & 1.327 & 0.630 & 0.697 & 0.727 & 1.640 & 2.287 & 0.291 \\
\hline 1991 & 0.523 & 1.318 & 0.613 & 0.704 & 0.726 & 1.616 & 2.287 & 0.292 \\
\hline 1992 & 0.526 & 1.331 & 0.618 & 0.712 & 0.731 & 1.627 & 2.324 & 0.294 \\
\hline
\end{tabular}


TABLE A2

Sensitivity of the Results to Alternative Assumptions ON THE EFFECT OF THE MiNIMUM WAGE

\begin{tabular}{|c|c|c|c|}
\hline \multicolumn{3}{|c|}{ Effect of the Minimum Wage on: } & \\
\hline & $\begin{array}{l}\text { Standard } \\
\text { Deviation }\end{array}$ & $10-50$ & $50-90$ \\
\hline \multicolumn{4}{|c|}{ (a) Baseline: $1979-1988$ with Minimum Wage $=\$ 3.00$} \\
\hline \multirow[t]{2}{*}{ Men } & 0.018 & 0.050 & -0.000 \\
\hline & $(24.8)$ & $(65.7)$ & $(-0.4)$ \\
\hline \multirow[t]{2}{*}{ Women } & 0.027 & 0.150 & -0.002 \\
\hline & $(30.2)$ & $(61.7)$ & $(-2.5)$ \\
\hline \multicolumn{4}{|c|}{ (b) Baseline with Disemployment Elasticity of 0.15} \\
\hline \multirow[t]{2}{*}{ Men } & 0.020 & 0.054 & 0.002 \\
\hline & $(28.6)$ & $(71.2)$ & $(1.7)$ \\
\hline \multirow[t]{2}{*}{ Women } & 0.029 & 0.148 & 0.003 \\
\hline & $(32.6)$ & $(60.7)$ & $(3.9)$ \\
\hline \multicolumn{4}{|c|}{ (c) Baseline with Wages Below the 1988 Minimum Unaffected } \\
\hline \multirow[t]{2}{*}{ Men } & 0.020 & 0.053 & -0.000 \\
\hline & $(28.1)$ & $(69.7)$ & $(-0.0)$ \\
\hline \multirow[t]{2}{*}{ Women } & 0.029 & 0.154 & -0.000 \\
\hline & $(32.4)$ & $(63.2)$ & $(-0.0)$ \\
\hline \multicolumn{4}{|c|}{ (d) $1979-1988$ with Minimum Wage $=\$ 2.90$} \\
\hline \multirow[t]{2}{*}{ Men } & 0.007 & 0.033 & -0.001 \\
\hline & $(9.7)$ & (43.7) & $(-1.3)$ \\
\hline \multirow[t]{2}{*}{ Women } & 0.014 & 0.118 & -0.003 \\
\hline & $(15.1)$ & $(48.7)$ & $(-3.3)$ \\
\hline \multicolumn{4}{|c|}{ (e) $1978-1988$ with Minimum Wage $=\$ 2.65$} \\
\hline \multirow[t]{2}{*}{ Men } & 0.008 & 0.032 & 0.001 \\
\hline & $(13.0)$ & $(47.6)$ & $(0.9)$ \\
\hline \multirow[t]{2}{*}{ Women } & 0.020 & 0.127 & 0.002 \\
\hline & $(23.4)$ & $(54.0)$ & $(2.3)$ \\
\hline
\end{tabular}

Note: Percent of total variation explained in parenthesis.

\section{APPENDIX}

\section{REFERENCES}

Blackburn, M., D. Bloom, and R. Freeman (1992): "Changes in Earnings Differentials in the 1980s: Concordance, Convergence, Causes and Consequences," NBER Working Paper 3901, National Bureau of Economic Research, Cambridge, MA.

Bound, J., AND G. Johnson (1992): "Changes in the Structure of Wages in the 1980s: An Evaluation of Alternative Explanations," American Economic Review, 82, 371-392.

Brown, C., C. Gilroy, AND A. Kohen (1982): "The Effect of the Minimum Wage on Employment and Unemployment," Journal of Economic Literature, 20, 487-528.

BUCHINSKY, M. (1994): "Changes in the U.S. Structure of Wages in the 1980s: An Application of Quantile Regressions," Econometrica, 62, 405-458.

CARD, D. (1996): "The Effect of Unions on the Structure of Wages: A Longitudinal Analysis," Econometrica, 64, 957-979.

CARD, D., AND A. KRueger (1994): "Minimum Wages and Employment: A Case Study of the Fast Food Industry in New Jersey and Pennsylvania," American Economic Review, 84, 772-793.

- (1995): Myth and Measurement: The New Economics of the Minimum Wage. Princeton: Princeton University Press. 
CARd, D., AND T. Lemieux (1996): "Wage Dispersion, Returns to Skill, and Black-White Differentials," Journal of Econometrics, 74, forthcoming.

DEvinE, T. J. (1993): "CPS Earnings and the Self-Employed: Words of Caution for Use and Interpretation," Working Paper, University of Chicago Population Research Center.

DiNardo, J., N. Fortin, AND T. LemieuX (1994): “Labor Market Institutions and the Distribution of Wages: A Semiparametric Approach,” Working Paper 0894, C.R.D.E., Université de Montréal, Montréal.

Freeman, R. (1980): "Unionism and the Dispersion of Wages," Industrial and Labor Relations Review, 34, 3-23.

- (1993): "How Much Has De-Unionization Contributed to the Rise in Male Earnings Inequality?" in Uneven Tides: Rising Inequality in America, ed. by S. Danziger and P. Gottschalk. New York: Russell Sage Foundation.

Freeman, R., AND K. NeEdels (1993): "Skill Differentials in Canada in an Era of Rising Labor Market Inequality," in Small Differences that Matter: Labor Markets and Income Maintenance in Canada and the United States, ed. by D. Card and R. Freeman. Chicago: University of Chicago Press and NBER.

FreEMAN, R. B., AND C. ICHNIOwSKI (1988): “Appendix A: Collective Organization of Labor in the Public Sector," in When Public Sector Workers Unionize, ed. R. B. Freeman and C. Ichniowski. Chicago: University of Chicago Press, pp. 365-398.

GRAMLICH, E. (1976): “The Impact of Minimum Wages on Other Wages, Employment, and Family Incomes," Brookings Papers on Economic Activity, 2, 409-451.

Grossman, J. B. (1983): “The Impact of the Minimum Wage on Other Wages," Journal of Human Resources, 18, 359-378.

Horrigan, M. W., AND R. B. Mincy (1993): "The Minimum Wage and Earnings and Income Inequality," in Uneven Tides: Rising Inequality in America, ed. by S. Danziger and P. Gottschalk. New York: Russell Sage Foundation.

Jones, M., J. MARron, AND B. PARK (1991): “A Simple Root $n$ Bandwidth Selector," The Annals of Statistics, 19, 1919-1932.

Juhn, C., K. MurPhy, AND B. PIERCE (1993): "Wage Inequality and the Rise in Returns to Skill," Journal of Political Economy, 101, 410-442.

KATZ, L., AND A. KRUEGer (1992): "The Effects of Minimum Wages on the Fast Food Industry," Industrial and Labor Relations Review, 46, 6-21.

KatZ, L., G. Loveman, AND D. Blanchflower (1995): "A Comparison of Changes in the Structure of Wages in Four OECD Countries," in Differences and Changes in Wage Structures, ed. by R. Freeman and L. Katz. Chicago: University of Chicago Press and NBER.

KATZ, L., AND K. MURPHY (1992): “Changes in Relative Wages, 1963-1987-Supply and Demand Factors," Quarterly Journal of Economics, 107, 35-78.

KATZ, L., AND A. Revenga (1989): "Changes in the Structure of Wages: The United States vs. Japan," Journal of the Japanese and International Economies, 3, 522-533.

Kullback, S., AND R. LeIBler (1951): “On Information and Sufficiency,” Annals of Mathematical Statistics, 22, 79-86.

LEMIEUX, T. (1993): "Unions and Wage Inequality in Canada and the United States," in Small Differences that Matter: Labor Markets and Income Maintenance in Canada and the United States, ed. by D. Card and R. Freeman. Chicago: University of Chicago Press and NBER.

LeSTER, R. (1964): Economics of Labor, 2nd ed. New York: The Macmillan Company.

LEVY, F., AND R. MURNANE (1992): "U.S. Earnings Levels and Earnings Inequality: A Review of Recent Trends and Proposed Explanations," Journal of Economic Literature, 30, 1331-1381.

LewIS, H. G. (1986): Union Relative Wage Effects: A Survey. Chicago: University of Chicago Press.

Lillard, L., J. P. Smith, AND F. Welch (1986): "What Do We Really Know about Wages? The Importance of Nonreporting and Census Imputation," Journal of Political Economy, 94, 489-506.

MACHIN, S., AND A. MANNING (1994): “The Effects of Minimum Wages on Wage Dispersion and Employment: Evidence from the U.K. Wage Councils," Industrial and Labor Relations Review, 47, 319-329. 
MURPhY, K., AND F. Welch (1991): “The Role of International Trade in Wage Differentials," in Workers and Their Wages: Changing Patterns in the United States, ed. by M. Kosters. Washington, D.C.: American Enterprise Institute.

(1992): "The Structure of Wages," Quarterly Journal of Economics, 107, 285-326.

OAXACA, R. (1973): "Male-Female Wage Differentials in Urban Labor Markets," International Economic Review, 14, 693-709.

PARK, B. U., AND B. A. TuRLACH (1992): "Practical Performance of Several Data Driven Bandwidth Selectors," Computational Statistics, 7, 251-270.

PARZEN, E. (1962): "On Estimation of a Probability Density Function and Mode," The Annals of Mathematical Statistics, 33, 1065-1076.

RosenblatT, M. (1956): "Remarks on Some Non-parametric Estimates of a Density Function," The Annals of Mathematical Statistics, 27, 832-837.

SheATHER, S., AND M. Jones (1991): "A Reliable Data-based Bandwidth Selection Method for Kernel Density Estimation," Journal of the Royal Statistical Society, B, 53, 683-690.

Silverman, B. (1986): Density Estimation for Statistics and Data Analysis. London: Chapman \& Hall.

Stigler, G. (1946): “The Economics of Minimum Wage Legislation," American Economic Review, $36,358-365$. 
http://www.jstor.org

\title{
LINKED CITATIONS
}

- Page 1 of 8 -

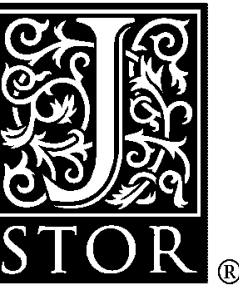

You have printed the following article:

Labor Market Institutions and the Distribution of Wages, 1973-1992: A Semiparametric Approach

John DiNardo; Nicole M. Fortin; Thomas Lemieux

Econometrica, Vol. 64, No. 5. (Sep., 1996), pp. 1001-1044.

Stable URL:

http://links.jstor.org/sici?sici=0012-9682\%28199609\%2964\%3A5\%3C1001\%3ALMIATD\%3E2.0.CO\%3B2-K

This article references the following linked citations. If you are trying to access articles from an off-campus location, you may be required to first logon via your library web site to access JSTOR. Please visit your library's website or contact a librarian to learn about options for remote access to JSTOR.

\section{[Footnotes]}

\author{
${ }^{2}$ U.S. Earnings Levels and Earnings Inequality: A Review of Recent Trends and Proposed \\ Explanations \\ Frank Levy; Richard J. Murnane \\ Journal of Economic Literature, Vol. 30, No. 3. (Sep., 1992), pp. 1333-1381. \\ Stable URL: \\ http://links.jstor.org/sici?sici=0022-0515\%28199209\%2930\%3A3\%3C1333\%3AUELAEI\%3E2.0.CO\%3B2-D
}

${ }^{3}$ Changes in the Structure of Wages in the 1980's: An Evaluation of Alternative Explanations John Bound; George Johnson

The American Economic Review, Vol. 82, No. 3. (Jun., 1992), pp. 371-392.

Stable URL:

http://links.jstor.org/sici?sici=0002-8282\%28199206\%2982\%3A3\%3C371\%3ACITSOW\%3E2.0.CO\%3B2-1

\footnotetext{
${ }^{4}$ Impact of Minimum Wages on Other Wages, Employment, and Family Incomes

Edward M. Gramlich; Robert J. Flanagan; Michael L. Wachter

Brookings Papers on Economic Activity, Vol. 1976, No. 2. (1976), pp. 409-461.

Stable URL:

http://links.jstor.org/sici?sici=0007-2303\%281976\%291976\%3A2\%3C409\%3AIOMWOO\%3E2.0.CO\%3B2-T
}

NOTE: The reference numbering from the original has been maintained in this citation list. 
http://www.jstor.org

\section{LINKED CITATIONS}

- Page 2 of 8 -

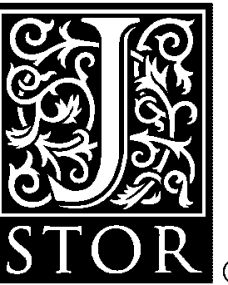

\footnotetext{
${ }^{8}$ Unionism and the Dispersion of Wages

Richard B. Freeman

Industrial and Labor Relations Review, Vol. 34, No. 1. (Oct., 1980), pp. 3-23.

Stable URL:

http://links.jstor.org/sici?sici=0019-7939\%28198010\%2934\%3A1\%3C3\%3AUATDOW\%3E2.0.CO\%3B2-L
}

\section{${ }^{10}$ Changes in Relative Wages, 1963-1987: Supply and Demand Factors}

Lawrence F. Katz; Kevin M. Murphy

The Quarterly Journal of Economics, Vol. 107, No. 1. (Feb., 1992), pp. 35-78.

Stable URL:

http://links.jstor.org/sici?sici=0033-5533\%28199202\%29107\%3A1\%3C35\%3ACIRW1S\%3E2.0.CO\%3B2-O

\section{${ }^{10}$ The Structure of Wages}

Kevin M. Murphy; Finis Welch

The Quarterly Journal of Economics, Vol. 107, No. 1. (Feb., 1992), pp. 285-326.

Stable URL:

http://links.jstor.org/sici?sici=0033-5533\%28199202\%29107\%3A1\%3C285\%3ATSOW\%3E2.0.CO\%3B2-4

\section{${ }^{10}$ Wage Inequality and the Rise in Returns to Skill}

Chinhui Juhn; Kevin M. Murphy; Brooks Pierce

The Journal of Political Economy, Vol. 101, No. 3. (Jun., 1993), pp. 410-442.

Stable URL:

http://links.jstor.org/sici?sici=0022-3808\%28199306\%29101\%3A3\%3C410\%3AWIATRI\%3E2.0.CO\%3B2-I

\section{${ }^{12}$ What Do We Really Know about Wages? The Importance of Nonreporting and Census Imputation}

Lee Lillard; James P. Smith; Finis Welch

The Journal of Political Economy, Vol. 94, No. 3, Part 1. (Jun., 1986), pp. 489-506.

Stable URL:

http://links.jstor.org/sici?sici=0022-3808\%28198606\%2994\%3A3\%3C489\%3AWDWRKA\%3E2.0.CO\%3B2-Q

\section{${ }^{14}$ A Simple Root $\mathbf{n}$ Bandwidth Selector}

M. C. Jones; J. S. Marron; B. U. Park

The Annals of Statistics, Vol. 19, No. 4. (Dec., 1991), pp. 1919-1932.

Stable URL:

http://links.jstor.org/sici?sici=0090-5364\%28199112\%2919\%3A4\%3C1919\%3AASRBS\%3E2.0.CO\%3B2-W

NOTE: The reference numbering from the original has been maintained in this citation list. 
http://www.jstor.org

\title{
LINKED CITATIONS
}

- Page 3 of 8 -

\author{
${ }^{16}$ The Effect of Unions on the Structure of Wages: A Longitudinal Analysis \\ David Card \\ Econometrica, Vol. 64, No. 4. (Jul., 1996), pp. 957-979. \\ Stable URL: \\ http://links.jstor.org/sici?sici=0012-9682\%28199607\%2964\%3A4\%3C957\%3ATEOUOT\%3E2.0.CO\%3B2-F
}

\author{
${ }^{18}$ The Effect of The Minimum Wage on Employment and Unemployment \\ Charles Brown; Curtis Gilroy; Andrew Kohen \\ Journal of Economic Literature, Vol. 20, No. 2. (Jun., 1982), pp. 487-528. \\ Stable URL: \\ http://links.jstor.org/sici?sici=0022-0515\%28198206\%2920\%3A2\%3C487\%3ATEOTMW\%3E2.0.CO\%3B2-C
}

\footnotetext{
${ }^{19}$ Impact of Minimum Wages on Other Wages, Employment, and Family Incomes

Edward M. Gramlich; Robert J. Flanagan; Michael L. Wachter

Brookings Papers on Economic Activity, Vol. 1976, No. 2. (1976), pp. 409-461.

Stable URL:

http://links.jstor.org/sici?sici=0007-2303\%281976\%291976\%3A2\%3C409\%3AIOMWOO\%3E2.0.CO\%3B2-T
}

\section{${ }^{19}$ The Effects of Minimum Wages on Wage Dispersion and Employment: Evidence from the U.K. Wages Councils}

Stephen Machin; Alan Manning

Industrial and Labor Relations Review, Vol. 47, No. 2. (Jan., 1994), pp. 319-329.

Stable URL:

http://links.jstor.org/sici?sici=0019-7939\%28199401\%2947\%3A2\%3C319\%3ATEOMWO\%3E2.0.CO\%3B2-7

${ }^{20}$ Changes in the Structure of Wages in the 1980's: An Evaluation of Alternative Explanations John Bound; George Johnson

The American Economic Review, Vol. 82, No. 3. (Jun., 1992), pp. 371-392.

Stable URL:

http://links.jstor.org/sici?sici=0002-8282\%28199206\%2982\%3A3\%3C371\%3ACITSOW\%3E2.0.CO\%3B2-1

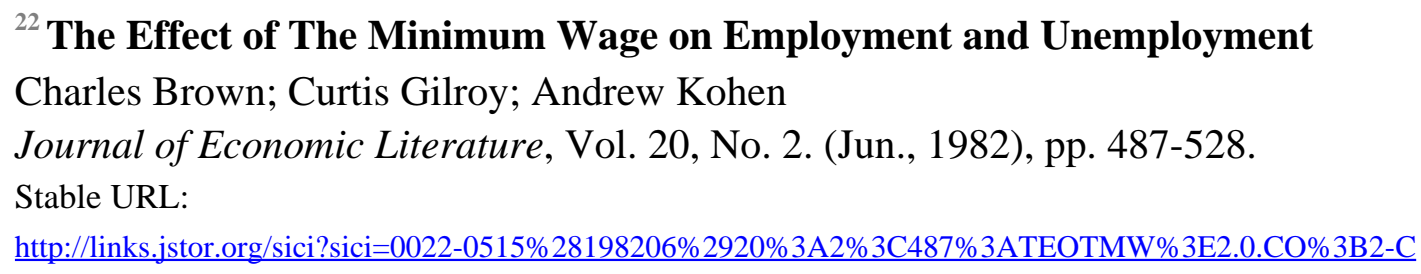

NOTE: The reference numbering from the original has been maintained in this citation list. 
http://www.jstor.org

\section{LINKED CITATIONS}

- Page 4 of 8 -

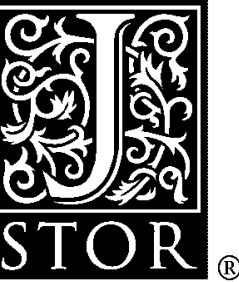

${ }^{25}$ Changes in the Structure of Wages in the 1980's: An Evaluation of Alternative Explanations John Bound; George Johnson

The American Economic Review, Vol. 82, No. 3. (Jun., 1992), pp. 371-392.

Stable URL:

http://links.jstor.org/sici?sici=0002-8282\%28199206\%2982\%3A3\%3C371\%3ACITSOW\%3E2.0.CO\%3B2-1

${ }^{29}$ The Effect of Unions on the Structure of Wages: A Longitudinal Analysis

David Card

Econometrica, Vol. 64, No. 4. (Jul., 1996), pp. 957-979.

Stable URL:

http://links.jstor.org/sici?sici=0012-9682\%28199607\%2964\%3A4\%3C957\%3ATEOUOT\%3E2.0.CO\%3B2-F

${ }^{31}$ Wage Inequality and the Rise in Returns to Skill

Chinhui Juhn; Kevin M. Murphy; Brooks Pierce

The Journal of Political Economy, Vol. 101, No. 3. (Jun., 1993), pp. 410-442.

Stable URL:

http://links.jstor.org/sici?sici=0022-3808\%28199306\%29101\%3A3\%3C410\%3AWIATRI\%3E2.0.CO\%3B2-I

\section{References}

Changes in the Structure of Wages in the 1980's: An Evaluation of Alternative Explanations John Bound; George Johnson

The American Economic Review, Vol. 82, No. 3. (Jun., 1992), pp. 371-392.

Stable URL:

http://links.jstor.org/sici?sici=0002-8282\%28199206\%2982\%3A3\%3C371\%3ACITSOW\%3E2.0.CO\%3B2-1

The Effect of The Minimum Wage on Employment and Unemployment

Charles Brown; Curtis Gilroy; Andrew Kohen

Journal of Economic Literature, Vol. 20, No. 2. (Jun., 1982), pp. 487-528.

Stable URL:

http://links.jstor.org/sici?sici=0022-0515\%28198206\%2920\%3A2\%3C487\%3ATEOTMW\%3E2.0.CO\%3B2-C

NOTE: The reference numbering from the original has been maintained in this citation list. 
http://www.jstor.org

\section{LINKED CITATIONS}

- Page 5 of 8 -

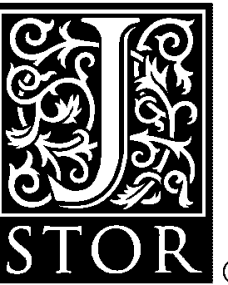

Changes in the U.S. Wage Structure 1963-1987: Application of Quantile Regression Moshe Buchinsky

Econometrica, Vol. 62, No. 2. (Mar., 1994), pp. 405-458.

Stable URL:

http://links.jstor.org/sici?sici=0012-9682\%28199403\%2962\%3A2\%3C405\%3ACITUWS\%3E2.0.CO\%3B2-H

The Effect of Unions on the Structure of Wages: A Longitudinal Analysis

David Card

Econometrica, Vol. 64, No. 4. (Jul., 1996), pp. 957-979.

Stable URL:

http://links.jstor.org/sici?sici=0012-9682\%28199607\%2964\%3A4\%3C957\%3ATEOUOT\%3E2.0.CO\%3B2-F

Minimum Wages and Employment: A Case Study of the Fast-Food Industry in New Jersey and Pennsylvania

David Card; Alan B. Krueger

The American Economic Review, Vol. 84, No. 4. (Sep., 1994), pp. 772-793.

Stable URL:

http://links.jstor.org/sici?sici=0002-8282\%28199409\%2984\%3A4\%3C772\%3AMWAEAC\%3E2.0.CO\%3B2-O

\section{Unionism and the Dispersion of Wages}

Richard B. Freeman

Industrial and Labor Relations Review, Vol. 34, No. 1. (Oct., 1980), pp. 3-23.

Stable URL:

http://links.jstor.org/sici?sici=0019-7939\%28198010\%2934\%3A1\%3C3\%3AUATDOW\%3E2.0.CO\%3B2-L

\section{Impact of Minimum Wages on Other Wages, Employment, and Family Incomes}

Edward M. Gramlich; Robert J. Flanagan; Michael L. Wachter

Brookings Papers on Economic Activity, Vol. 1976, No. 2. (1976), pp. 409-461.

Stable URL:

http://links.jstor.org/sici?sici=0007-2303\%281976\%291976\%3A2\%3C409\%3AIOMWOO\%3E2.0.CO\%3B2-T

\section{The Impact of the Minimum Wage on Other Wages}

Jean Baldwin Grossman

The Journal of Human Resources, Vol. 18, No. 3. (Summer, 1983), pp. 359-378.

Stable URL:

http://links.jstor.org/sici?sici=0022-166X\%28198322\%2918\%3A3\%3C359\%3ATIOTMW\%3E2.0.CO\%3B2-\%23

NOTE: The reference numbering from the original has been maintained in this citation list. 
http://www.jstor.org

\title{
LINKED CITATIONS
}

- Page 6 of 8 -

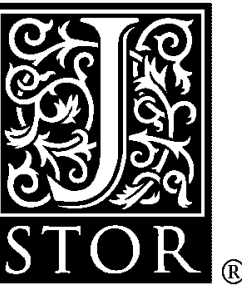

\author{
A Simple Root $\mathbf{n}$ Bandwidth Selector \\ M. C. Jones; J. S. Marron; B. U. Park \\ The Annals of Statistics, Vol. 19, No. 4. (Dec., 1991), pp. 1919-1932. \\ Stable URL: \\ http://links.jstor.org/sici?sici=0090-5364\%28199112\%2919\%3A4\%3C1919\%3AASRBS\%3E2.0.CO\%3B2-W
}

Wage Inequality and the Rise in Returns to Skill

Chinhui Juhn; Kevin M. Murphy; Brooks Pierce

The Journal of Political Economy, Vol. 101, No. 3. (Jun., 1993), pp. 410-442.

Stable URL:

http://links.jstor.org/sici?sici=0022-3808\%28199306\%29101\%3A3\%3C410\%3AWIATRI\%3E2.0.CO\%3B2-I

\section{The Effect of the Minimum Wage on the Fast-Food Industry}

Lawrence F. Katz; Alan B. Krueger

Industrial and Labor Relations Review, Vol. 46, No. 1. (Oct., 1992), pp. 6-21.

Stable URL:

http://links.jstor.org/sici?sici=0019-7939\%28199210\%2946\%3A1\%3C6\%3ATEOTMW\%3E2.0.CO\%3B2-S

\section{Changes in Relative Wages, 1963-1987: Supply and Demand Factors}

Lawrence F. Katz; Kevin M. Murphy

The Quarterly Journal of Economics, Vol. 107, No. 1. (Feb., 1992), pp. 35-78.

Stable URL:

http://links.jstor.org/sici?sici=0033-5533\%28199202\%29107\%3A1\%3C35\%3ACIRW1S\%3E2.0.CO\%3B2-O

\section{On Information and Sufficiency}

S. Kullback; R. A. Leibler

The Annals of Mathematical Statistics, Vol. 22, No. 1. (Mar., 1951), pp. 79-86.

Stable URL:

http://links.jstor.org/sici?sici=0003-4851\%28195103\%2922\%3A1\%3C79\%3AOIAS\%3E2.0.CO\%3B2-3

\author{
U.S. Earnings Levels and Earnings Inequality: A Review of Recent Trends and Proposed \\ Explanations \\ Frank Levy; Richard J. Murnane \\ Journal of Economic Literature, Vol. 30, No. 3. (Sep., 1992), pp. 1333-1381. \\ Stable URL: \\ http://links.jstor.org/sici?sici=0022-0515\%28199209\%2930\%3A3\%3C1333\%3AUELAEI\%3E2.0.CO\%3B2-D
}

NOTE: The reference numbering from the original has been maintained in this citation list. 
http://www.jstor.org

\section{LINKED CITATIONS}

- Page 7 of 8 -

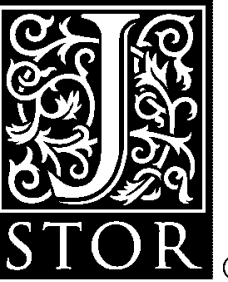

\section{What Do We Really Know about Wages? The Importance of Nonreporting and Census Imputation}

Lee Lillard; James P. Smith; Finis Welch

The Journal of Political Economy, Vol. 94, No. 3, Part 1. (Jun., 1986), pp. 489-506.

Stable URL:

http://links.jstor.org/sici?sici=0022-3808\%28198606\%2994\%3A3\%3C489\%3AWDWRKA\%3E2.0.CO\%3B2-Q

The Effects of Minimum Wages on Wage Dispersion and Employment: Evidence from the U.K. Wages Councils

Stephen Machin; Alan Manning

Industrial and Labor Relations Review, Vol. 47, No. 2. (Jan., 1994), pp. 319-329.

Stable URL:

http://links.jstor.org/sici?sici=0019-7939\%28199401\%2947\%3A2\%3C319\%3ATEOMWO\%3E2.0.CO\%3B2-7

The Structure of Wages

Kevin M. Murphy; Finis Welch

The Quarterly Journal of Economics, Vol. 107, No. 1. (Feb., 1992), pp. 285-326.

Stable URL:

http://links.jstor.org/sici?sici=0033-5533\%28199202\%29107\%3A1\%3C285\%3ATSOW\%3E2.0.CO\%3B2-4

\section{Male-Female Wage Differentials in Urban Labor Markets}

Ronald Oaxaca

International Economic Review, Vol. 14, No. 3. (Oct., 1973), pp. 693-709.

Stable URL:

http://links.jstor.org/sici?sici=0020-6598\%28197310\%2914\%3A3\%3C693\%3AMWDIUL\%3E2.0.CO\%3B2-7

\section{On Estimation of a Probability Density Function and Mode}

Emanuel Parzen

The Annals of Mathematical Statistics, Vol. 33, No. 3. (Sep., 1962), pp. 1065-1076.

Stable URL:

http://links.jstor.org/sici?sici=0003-4851\%28196209\%2933\%3A3\%3C1065\%3AOEOAPD\%3E2.0.CO\%3B2-C

\section{Remarks on Some Nonparametric Estimates of a Density Function}

Murray Rosenblatt

The Annals of Mathematical Statistics, Vol. 27, No. 3. (Sep., 1956), pp. 832-837.

Stable URL:

http://links.jstor.org/sici?sici=0003-4851\%28195609\%2927\%3A3\%3C832\%3AROSNEO\%3E2.0.CO\%3B2-X

NOTE: The reference numbering from the original has been maintained in this citation list. 
http://www.jstor.org

\section{LINKED CITATIONS \\ - Page 8 of 8 -}

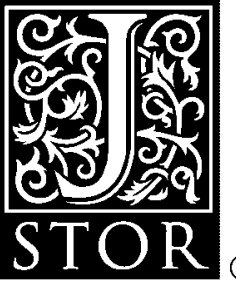

\section{The Economics of Minimum Wage Legislation}

\section{George J. Stigler}

The American Economic Review, Vol. 36, No. 3. (Jun., 1946), pp. 358-365.

Stable URL:

http://links.jstor.org/sici?sici=0002-8282\%28194606\%2936\%3A3\%3C358\%3ATEOMWL\%3E2.0.CO\%3B2-A 